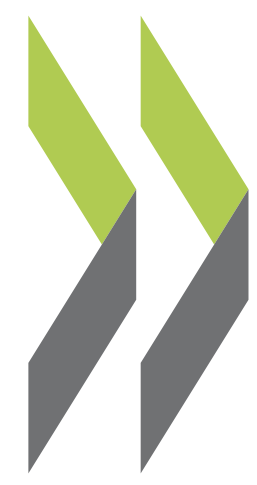

OECD Economics Department Working Papers No. 1211

Lilas Demmou,

Spurring Growth in Lagging Martin Haluš, Regions in Slovak Republic

Gabriel Machlica, Robert Menkyna 
Organisation de Coopération et de Développement Économiques

Organisation for Economic Co-operation and Development

28-Apr-2015

ECONOMICS DEPARTMENT

English - Or. English

\section{SPURRING GROWTH IN LAGGING REGIONS IN THE SLOVAK REPUBLIC}

ECONOMICS DEPARTMENT WORKING PAPERS No. 1211

By Lilas Demmou, Martin Haluš, Gabriel Machlica and Robert Menkyna

OECD Working Papers should not be reported as representing the official views of the OECD or of its member countries. The opinions expressed and arguments employed are those of the author(s)

Authorised for publication by Robert Ford, Deputy Director, Country Studies Branch, Economics Department.

All Economics Department Working Papers are available at www.oecd.org/eco/workingpapers.

JT03375303

Complete document available on OLIS in its original format

This document and any map included herein are without prejudice to the status of or sovereignty over any territory, to the delimitation of international frontiers and boundaries and to the name of any territory, city or area. 
OECD Working Papers should not be reported as representing the official views of the OECD or of its member countries. The opinions expressed and arguments employed are those of the author(s).

Working Papers describe preliminary results or research in progress by the author(s) and are published to stimulate discussion on a broad range of issues on which the OECD works.

Comments on Working Papers are welcomed, and may be sent to OECD Economics Department, 2 rue André-Pascal, 75775 Paris Cedex 16, France, or by e-mail to eco.contact@oecd.org.

This document and any map included herein are without prejudice to the status of or sovereignty over any territory, to the delimitation of international frontiers and boundaries and to the name of any territory, city or area.

The statistical data for Israel are supplied by and under the responsibility of the relevant Israeli authorities. The use of such data by the OECD is without prejudice to the status of the Golan Heights, East Jerusalem and Israeli settlements in the West Bank under the terms of international law.

(C) OECD (2015)

You can copy, download or print OECD content for your own use, and you can include excerpts from OECD publications, databases and multimedia products in your own documents, presentations, blogs, websites and teaching materials, provided that suitable acknowledgment of OECD as source and copyright owner is given. All requests for commercial use and translation rights should be submitted to rights@oecd.org 


\section{ABSTRACT/RÉSUMÉ \\ Spurring Growth in Lagging Regions in Slovak Republic}

Regional inequality in Slovakia is among the highest in the OECD and is increasing. The main reason for regional disparity is the combination of low economic growth and job creation in the eastern and central part of the country and insufficient labour mobility to the west, in particular by low-skilled workers. As a result, jobs shortage and lack of technological capacities in the central and eastern regions persist alongside skills shortages in the Bratislava regions. Boosting convergence requires a multi-pronged approach involving innovation, labour market and educational policies. Completing the transport infrastructure network in Slovakia will be both important for removing expansion bottlenecks in the Bratislava region and reducing obstacles for job creation in the central and eastern regions.

This Working Paper relates to the 2014 OECD Economic Survey of the Slovak Republic (www.oecd.org/eco/surveys/economic-survey-slovak-republic.htm).

JEL Classification: J21, J24, J31, I2, I3, J61, O3, R3, R4

Keywords: regional inequality, unemployment, active labour market policies, training, public employment services, lifelong learning, education, VET, Roma, transport infrastructure, innovation, EU funds.

\section{Stimuler la croissance dans les régions les moins dynamiques en République Slovaque}

Les inégalités entre régions slovaques figurent parmi les plus fortes de la zone OCDE et s'accentuent. Ces disparités régionales s'expliquent principalement par la conjonction d'une croissance économique atone, de faibles créations d'emplois dans l'est et le centre du pays et d'une mobilité insuffisante de la maind'œuvre vers l'ouest, en particulier pour les travailleurs peu qualifiés. En conséquence, une pénurie d'emplois et un manque de capacités technologiques perdurent dans les régions du centre et de l'est, parallèlement à des pénuries de qualifications dans la région de Bratislava. Le renforcement de la convergence entre régions passe par une approche pluridimensionnelle, axée sur l'innovation, le marché du travail et les politiques d'éducation. Il importe de compléter le réseau d'infrastructures de transport en Slovaquie à la fois pour supprimer les goulets d'étranglement qui limitent l'expansion économique dans la région de Bratislava, et pour réduire les obstacles à la création d'emplois dans les régions du centre et de l'est.

Ce document de travail se rapporte à l'Étude économique de l'OCDE 2014 sur le République Slovaque (www.oecd.org/fr/eco/etudes/etude-economique-republique-slovaque.htm).

Classification JEL : J21, J24, J31, I2, I3, J61, O3, R3, R4

Mots clés: Inegalité regionale, chomage, politiques actives du marché du travail, formation, services publiques de l'emploi, formation continue, éducation, enseignement et formation professionnelle, inégalité, population Rome, infrastructures de transport, innovation, fonds Européens. 


\section{TABLE OF CONTENTS}

Spurring growth in lagging regions in the Slovak Republic .....................................................................

Regional inequality is high, increasing and associated with poor quality of life ...................................

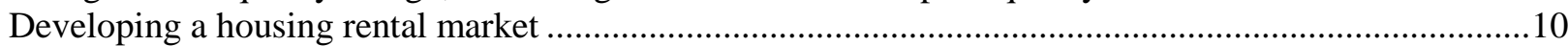

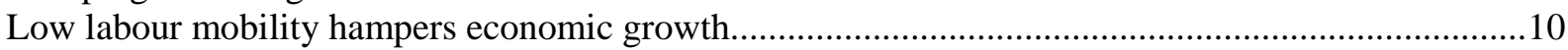

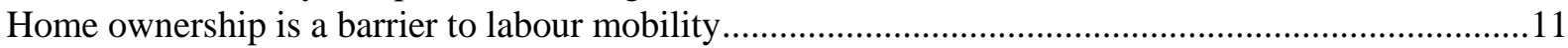

Public policies should further encourage the development of a rental market.......................................12

Improving the employability of low-skilled workers by stepping up active labour market policies ..........14

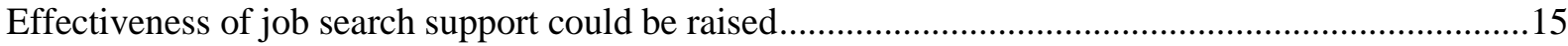

Active labour market policies need to be refined to meet regional needs .............................................17

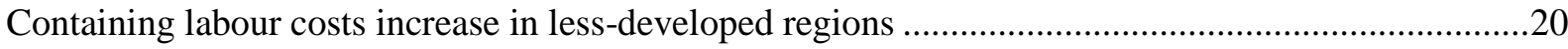

Aligning educational policies with employment objectives .................................................................21

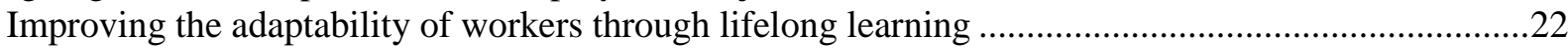

Ensuring a better matching of skills with labour market needs for vocational education ......................22

Raising the overall level of basic skills and increasing equality of opportunity ..................................24

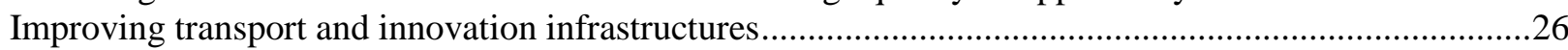

The connection between lagging regions with the core economic centre needs to be improved ............26

Spurring technology adoption in lagging regions to increase competitiveness....................................29

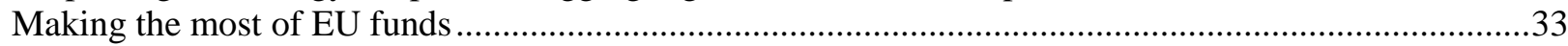

There is room to strengthen the impact of EU funds on regional convergence ....................................34

The allocation of funds among priorities is consistent with the main Slovak challenges .......................35

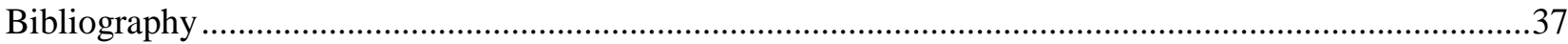

\section{Tables}

1. Distribution of public support between home ownership and rental housing .......................................12

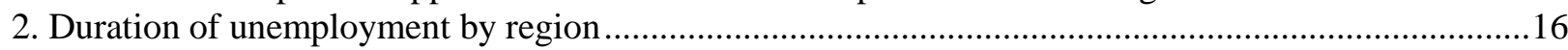

3 Allocation of resources among activation programmes: national and regional ....................................18

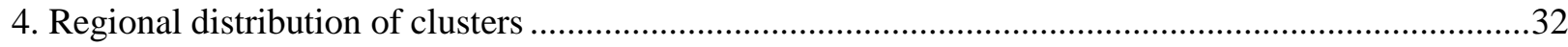

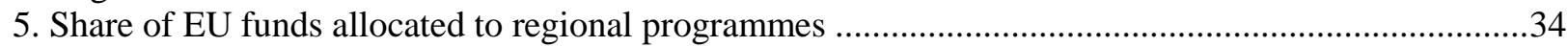

\section{Figures}

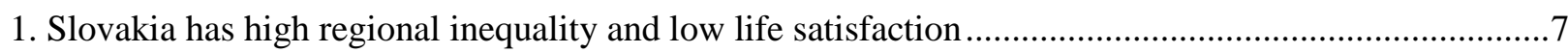

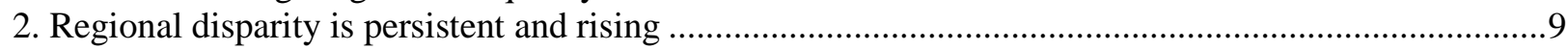

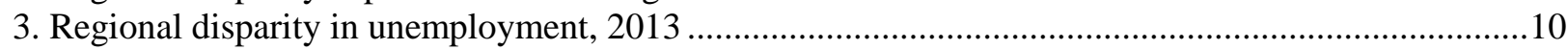

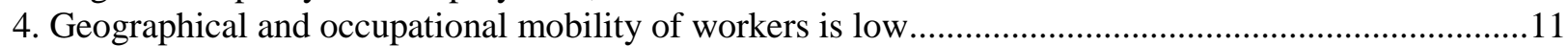

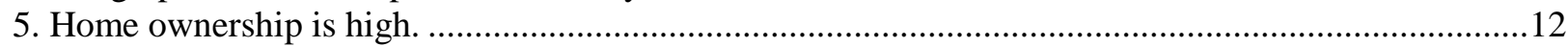

6. Low skilled unemployment is the main challenge for Slovakia. ........................................................14

7. There is room for higher resources and efficiency in Public Employment Services ............................15

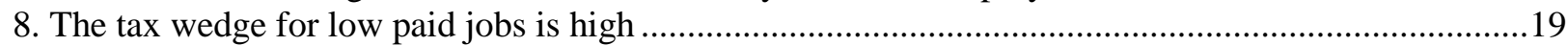

9. Minimum wage needs to adapt to local labour market conditions........................................................20

10. Lifelong learning is almost non-existent in lagging regions ..........................................................22

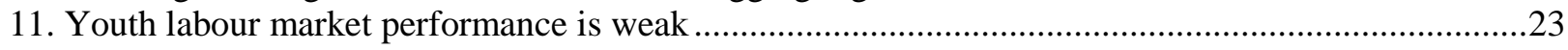

12. Uneven resources of vocational education and training institutions should be avoided......................24 


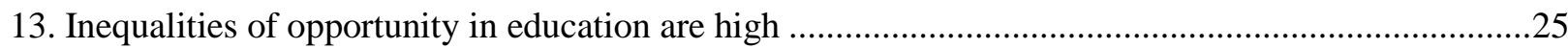

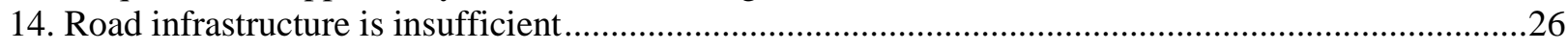

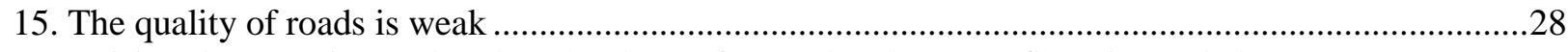

16. Raising the capacity to absorb technology of central and eastern firms is needed ..............................30

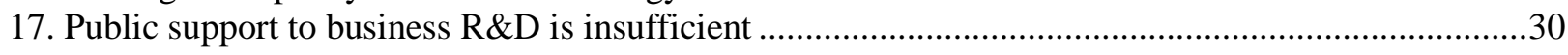

18. Slovakia is a main beneficiary from EU cohesion and structural funds in 2014-20 ..........................33

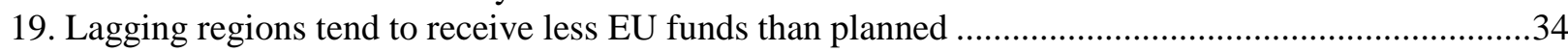

20. Sectoral allocation of EU funds are in line with growth challenges ..................................................35

\section{Boxes}

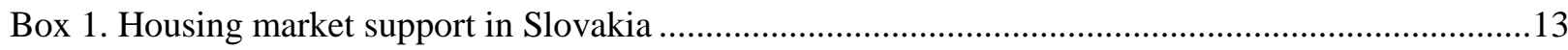

Box 2. Ongoing reform of public employment services .................................................................... 16

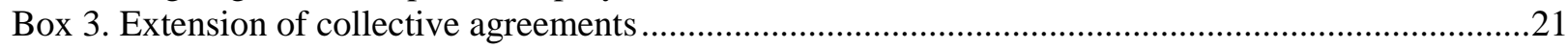

Box 4. Main characteristics of the Public Procurement Act reform .....................................................27

Box 5. Main barriers that have slowed highway construction .............................................................28

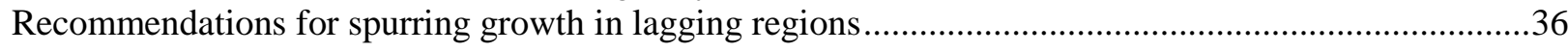


ECO/WKP(2015)29 


\title{
SPURRING GROWTH IN LAGGING REGIONS IN THE SLOVAK REPUBLIC
}

\author{
By Lilas Demmou, Martin Haluš, Gabriel Machlica and Robert Menkyna ${ }^{1}$
}

1. Individual income inequality in Slovakia is low, but regional inequality is high, which means that low income earners are regionally concentrated. Regional inequality is apparent in terms of GDP per capita, income, employment and poverty indicators (OECD, 2013a). The life satisfaction index is also significantly below the OECD average and regional disparities are striking; more than $80 \%$ of the population in the east believe that their situation and chances for improvement are worse compared with the rest of the country, while only 13\% share this thinking in Bratislava (Figure 1). Higher and more inclusive growth facilitating regional convergence is needed to counter the geographical dualisation.

Figure 1. Slovakia has high regional inequality and low life satisfaction

A. Regional GDP inequality vs. Life satisfaction

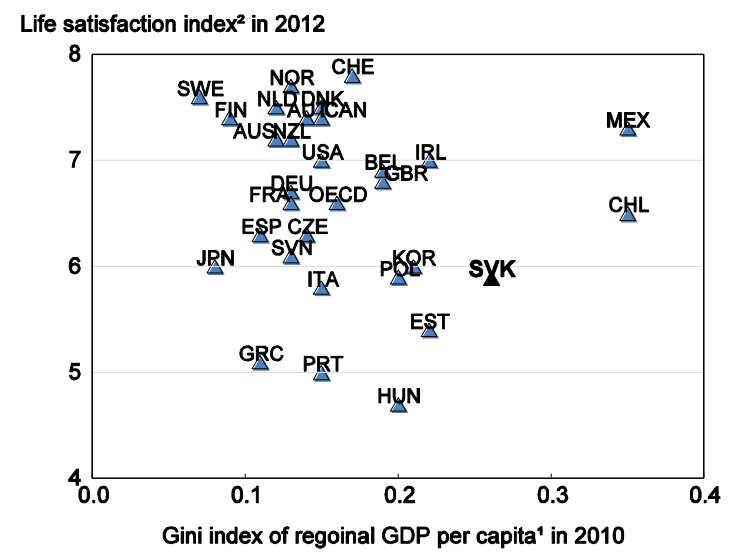

B. Perception of regional disparities $\%$ of responses ${ }^{3}$ in 2010

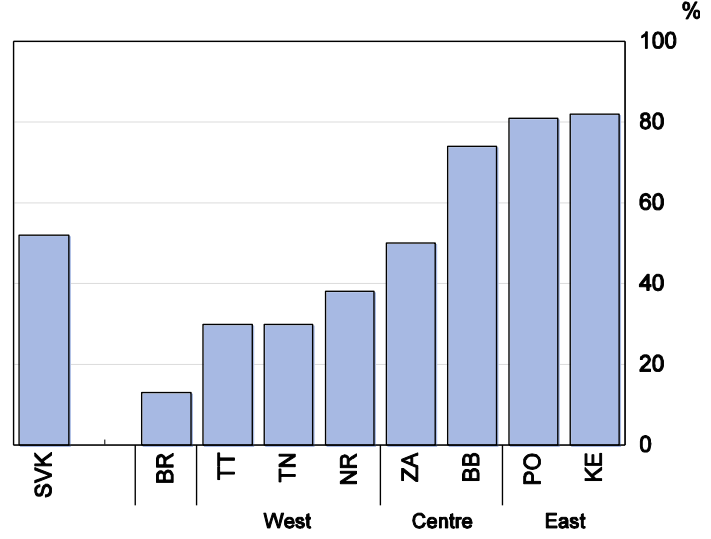

Note: Bratislava (BR), Trnava (TT), Trenčín (TN), Nitra (NR), Žilina (ZA), Banská Bystrica (BB), Prešov (PO) and Košice (KE).

1. Regions of the OECD countries are classified according to two territorial levels: the high level (TL2) and the low level (TL3). Regions at TL2 are divided into smaller regions at TL3. TL3 level data are used except for Australia, Canada, Chile, Mexico and United States.

2. The indicator is measured as a weighted-sum of different response categories based on people's rates of their current life relative to the best and worst possible lives for them on a scale from 0 to 10 , using the Cantril Ladder.

3. Percentage of responses to the following question: Do you think the situation and chances of the population living in your regions are "worse" compared to the average of Slovakia?

Source: OECD (2013), Regions at a Glance, OECD Better Life Index Database and Institute for Public Affairs.

1. Lilas Demmou was acting Head of the Slovak Desk at the Economics Department of the OECD in Paris, Martin Haluš and Gabriel Machlica were secondees from the Institute for Financial Policy in Slovakia and Robert Menkyna was consultant from CERGE-EI Institute in Czech Republic. This paper was originally produced for the 2014 OECD Economic Survey of the Slovak Republic and published in November 2014, under the authority of the Economic and Development Review Committee (EDRC). The authors are grateful to Alvaro Pereira, Bob Ford, and Andreas Wörgötter for their guidance. They would like to thank Hansjoerg Bloechliger, Aida Caldera-Sanchez, Jens Hoj, Andreas Kappeler and Yana Vaziakova (at the Economics Department), Dorothé Allain-Dupre, Isabelle Chatry, Jose Enrique Garcilazo, Joaquim Oliveira Martins and Rafaelle Trapasso (at the Public Governance and Territorial Development Directorate), Yuri Belfali and Claire Shewbridge (at the Education Directorate), Dirk Pilat (at the Science, Technology and Industry Directorate), the Slovak authorities and members of the EDRC for their comments. Special thanks go to Artur Radziwill for valuable discussions when he was working at the OECD. The authors would also like to thank Seung-Hee Koh for statistical research. Technical preparation was provided by Heloise Wickramanayake and Mercedes Burgos. 
2. The main reason for regional disparity is the combination of low economic growth and job creation in the eastern and central part of the country and insufficient labour mobility to the west, in particular by low-skilled workers. Promoting regional growth requires the adoption of a multi-pronged approach, which combines personal and regional aspects. Such a comprehensive programme needs to focus on developing the rental housing market, stepping up ALMPs, making education more employmentfocused, completing transport infrastructure and targeting innovation policies to regional needs, together with public sector reform (OECD 2014d). Some issues were already identified as essential challenges in former Economic Surveys of the Slovak Republic (2012, 2009). A new look at those questions is provided in light of regional challenges.

3. The paper begins with an assessment of regional disparities leading to a clear picture of a booming west and a lagging east. It then discusses barriers to the regional mobility of workers, which could help in adjusting the labour market at the national level, but which is among the lowest of OECD countries due to the absence of a rental housing market and insufficient transport infrastructure. Labour market performance of low-skilled workers is one of the worst among OECD countries, and the picture is even more dramatic in the east. Stepping up the ALMPs, strengthening job-search support and containing labour costs would improve their job prospects. Increasing the education level and improving the schoolto-work transition would also increase the employability of eastern workers and productivity, spurring the attractiveness of the east for firms. Similarly, developing transport infrastructure and technological capacity would attract more investment and job creation in less-developed regions.

\section{Regional inequality is high, increasing and associated with poor quality of life}

4. Regional disparities in Slovakia are among the highest in the OECD countries. GDP per capita in the Bratislava region is more than twice the national average, while in the east (Presov), GDP per capita is less than $60 \%$ of the national average. More than half of the population lives in less-developed regions where GDP per capita is below the median estimated at EUR 11150 in 2011 (Figure 2, Panel A).

5. Regional disparities are also apparent in income and labour utilization (Figure 2, Panel B). The average income in the east is less than half of that in Bratislava. The difference between the highest regional unemployment rate $(19.6 \%)$ and the lowest $(6.4 \%)$ is high. On the basis of unemployment rates, regions can be divided into two broad groups: richer western regions comprising Bratislava, Trnava, Trenčín, and Nitra, and poorer eastern regions comprising Žilina, Banská Bystrica, Presov, and Kosice, hereafter called also lagging regions (Figure 3). Overall, two thirds of the unemployed live in the eastern regions. Among the Roma, who mainly live in the east of the country, only $20 \%$ of men and less than $10 \%$ of women participate in the formal labour market (World Bank, 2012). As a result of low job prospects, almost $17 \%$ of people in the east are below the at-risk-of poverty threshold (60\% of median income) compared with only $6 \%$ in Bratislava. People entitled to benefits that cover material needs are about eleven times more numerous in the east compared with the Bratislava region (Central Labour Office).

6. Regional disparities are persistent and rising over time (Banerjee and Jarmuzek, 2009). The increase in the regional Gini coefficient has been one of the highest among OECD countries since the transition and it has accelerated since the economic crisis. Almost $40 \%$ of the unemployment increase since 2009 was concentrated in the eastern regions and long-term unemployment accounts for $70 \%$, while western regions benefit from strong economic growth and labour market performance (Figure 2. Panels C and D). 
ECO/WKP(2015)29

Figure 2. Regional disparities are persistent and rising

A. Inequality of GDP per caplta across reglons'
2010

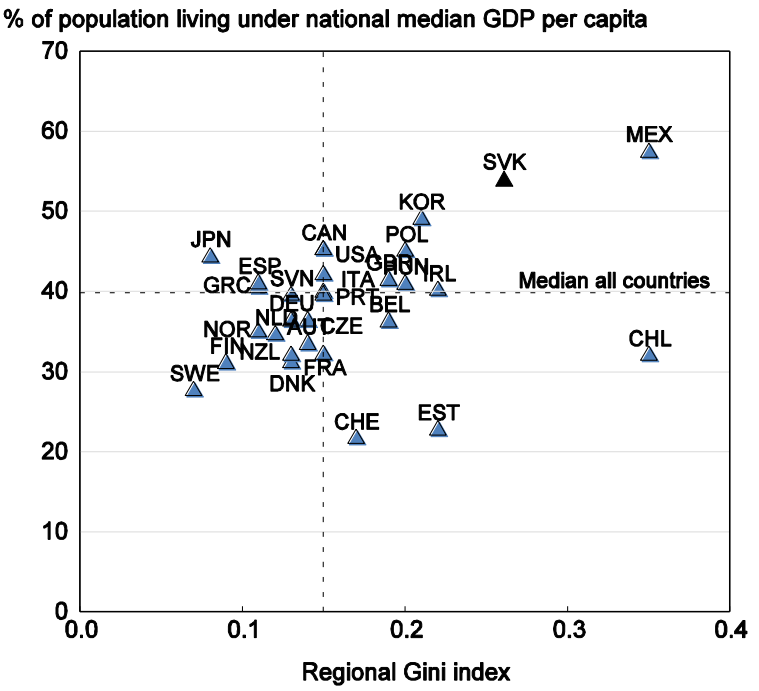

C. Long term changes In the reglonal GInl Index of GDP per caplta

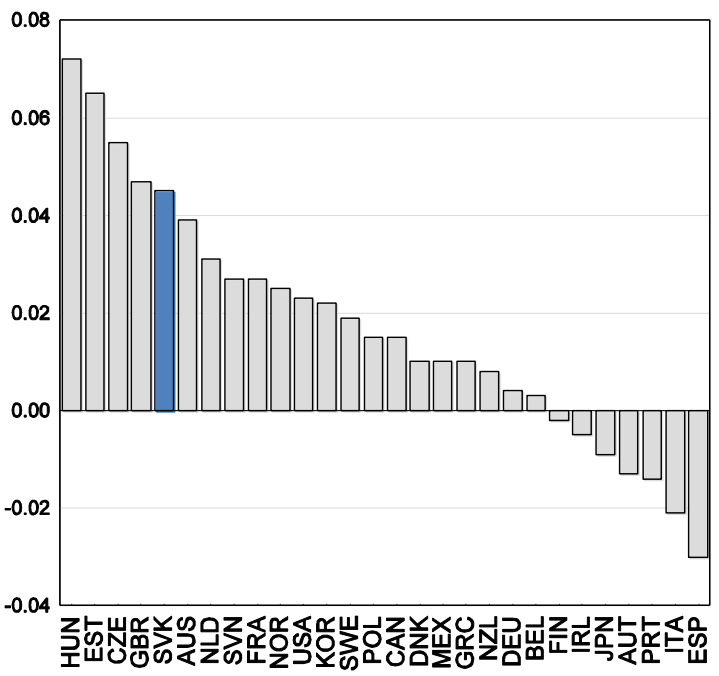

B. Reglonal dlsparltles: unemployment and household Income

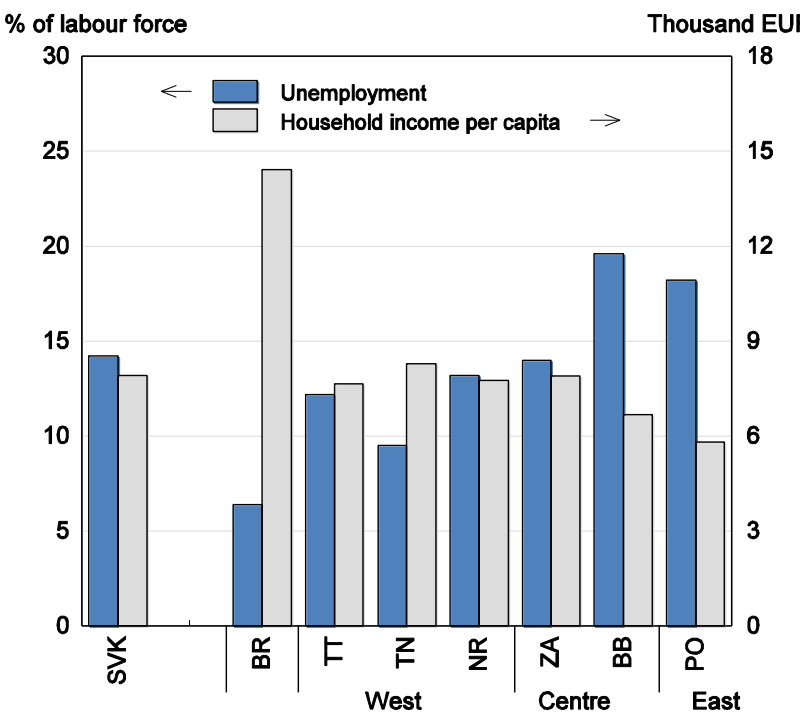

D. Reglonal dlsparitles: unemployment and GDP per caplta 2008-2011

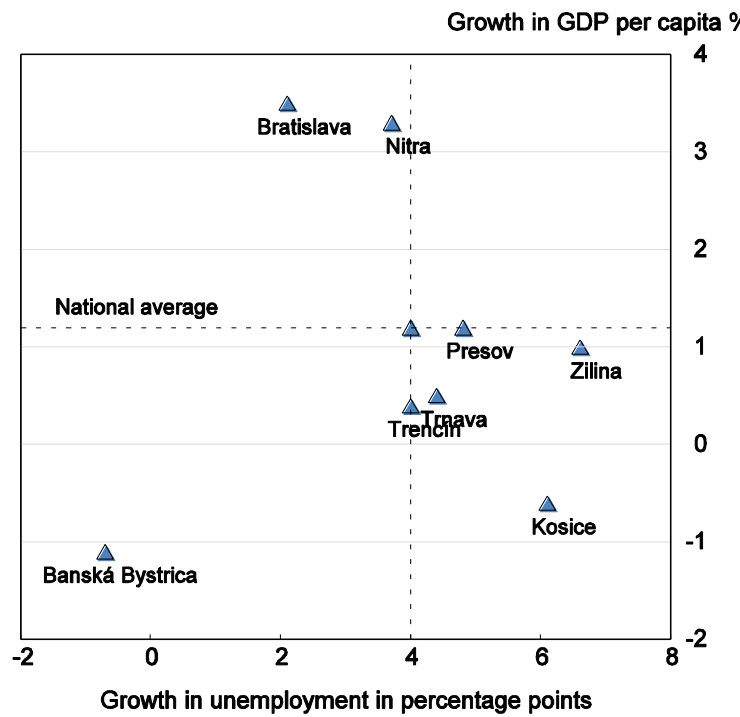

Note: Bratislava (BR), Trnava (TT), Trenčín (TN), Nitra (NR), Žilina (ZA), Banská Bystrica (BB), Prešov (PO) and Košice (KE).

1. Regions of the OECD countries are classified according to two territorial levels: the high level (TL2) and the low level (TL3). Regions at TL2 are divided into smaller regions at TL3. TL3 level data are used except for Australia, Canada, Chile, Mexico and United States.

Source: OECD (2013), Regions at a Glance and Statistical Office of the Slovak Republic. 


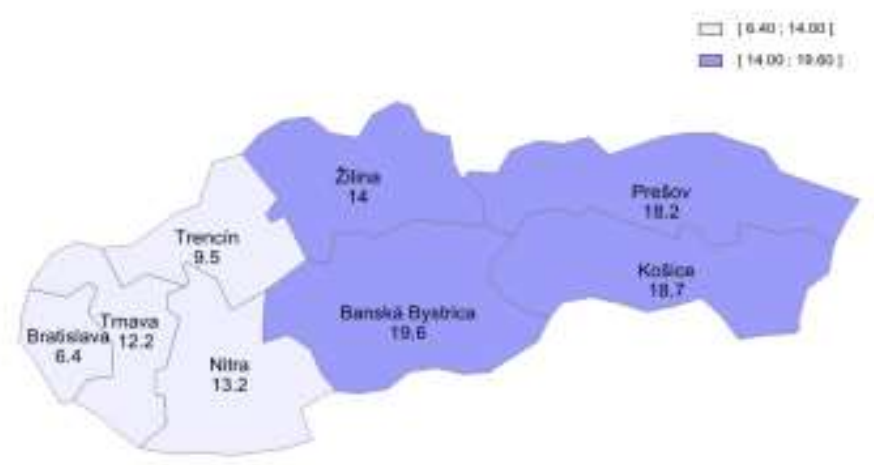

Source: Statistical Office of the Slovak Republic.

Developing a housing rental market

\section{Low labour mobility hampers economic growth}

7. Bratislava has scope to expand its agglomeration, which is relatively small. Higher growth in the economically successful regions would help reduce the unemployment rate in the east and stimulate productivity in the west by a better matching process as well as agglomeration effects (Ahrend et al., 2014). International experience suggests that doubling the size of an agglomeration could increase productivity by $2-8 \%$, depending on the sector (Rosenthal and Strange, 2004; Combes, 2008).

8. Mobility of workers is very low in Slovakia, however, and the adjustment of the Slovak labour market via migration has been weak (Fidrmuc, 2004). Less than 2\% of Slovaks from 15 to 64 moved in 2011, and of those only a quarter moved between regions (Vagac, 2013). There are no substantial differences in mobility across age and education attainment, contrary to other OECD countries, implying that a common factor explains low regional mobility (Hüfner, 2009; OECD, 2005a). Low residential mobility is associated with low labour turnover, suggesting that barriers to residential mobility hamper the reallocation of workers to adjust to job opportunities (Andrews et al., 2011; Figure 4). 
Figure 4. Geographical and occupational mobility of workers is low

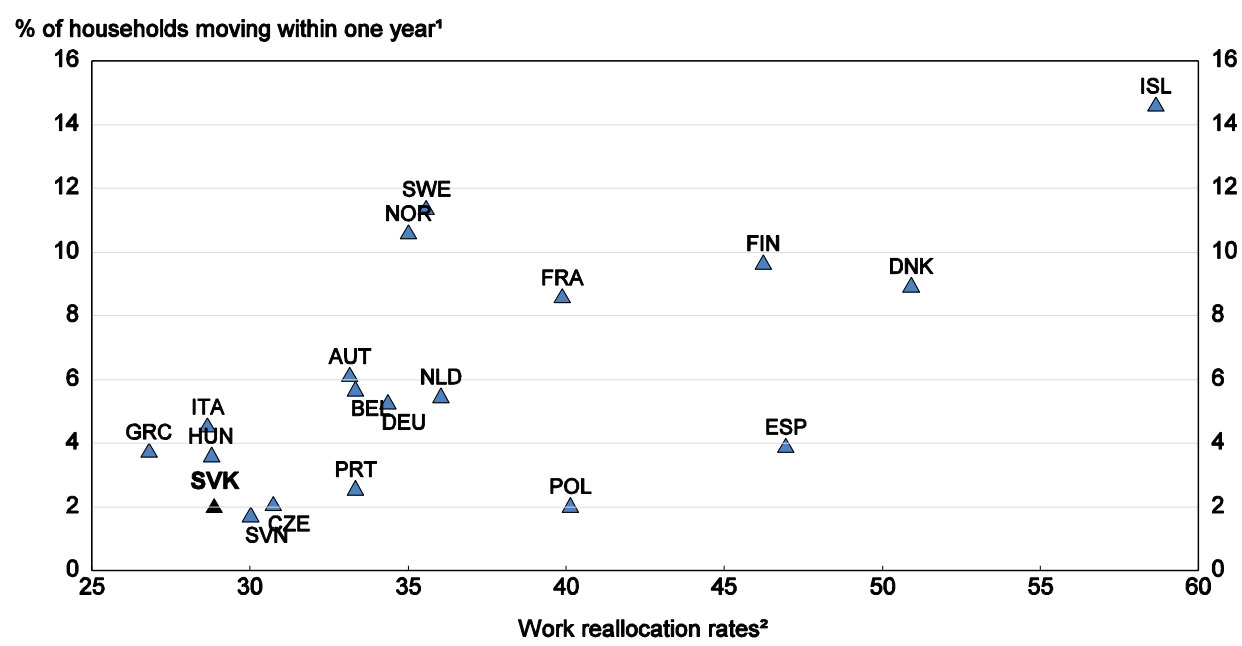

1. Mobility rates are annualised. The low mobility rate in some Eastern European countries cannot be verified independently.

2. Work reallocation rates (hiring and firing rates) are expressed in percentage of total dependent employment. See OECD.

Source: OECD (2011), Economic Policy Reforms: Going for Growth; Employment Outlook (2010).

\section{Home ownership is a barrier to labour mobility}

9. In general home ownership reduces residential mobility of workers due notably to potential capital losses (OECD, 2005a; von Ommeren and Leuvensteijn, 2005). Empirical evidence suggests that a 10 percentage point rise in the owner-occupation rate may be associated with an increase in the unemployment rate up to 2 percentage points due to lower mobility (Oswald, 1996; Nickell, 1998). With $90 \%$ of Slovaks owing their own home, ownership is among the highest in OECD countries (Figure 5, Panel A). Moreover, a very large majority of owners do not have any loans to pay as they bought their flats after the transition from communism at a discounted price. This contributes to lowering further labour mobility as owners with a monthly mortgage have a greater incentive to avoid unemployment and hence to move to improve their labour market perspectives (Andrews et al., 2011). On average in OECD countries, an owner without a mortgage is estimated to be $13 \%$ less likely to move every year than a private renter, while a mortgage owner's yearly mobility rate is some $9 \%$ lower than that of a renter (OECD, 2011a).

10. The absence of a functioning rental market is accompanied by poor living conditions. The share of residents that live in crowded conditions has reached $40 \%$ in Slovakia, one of the highest rates observed in European countries (Figure 5, Panel B). Overcrowding suggests that dwellings are insufficient and demand for rental houses is potentially high (CECODHAS, 2012; Vagac, 2013). 
Figure 5. Home ownership is high.
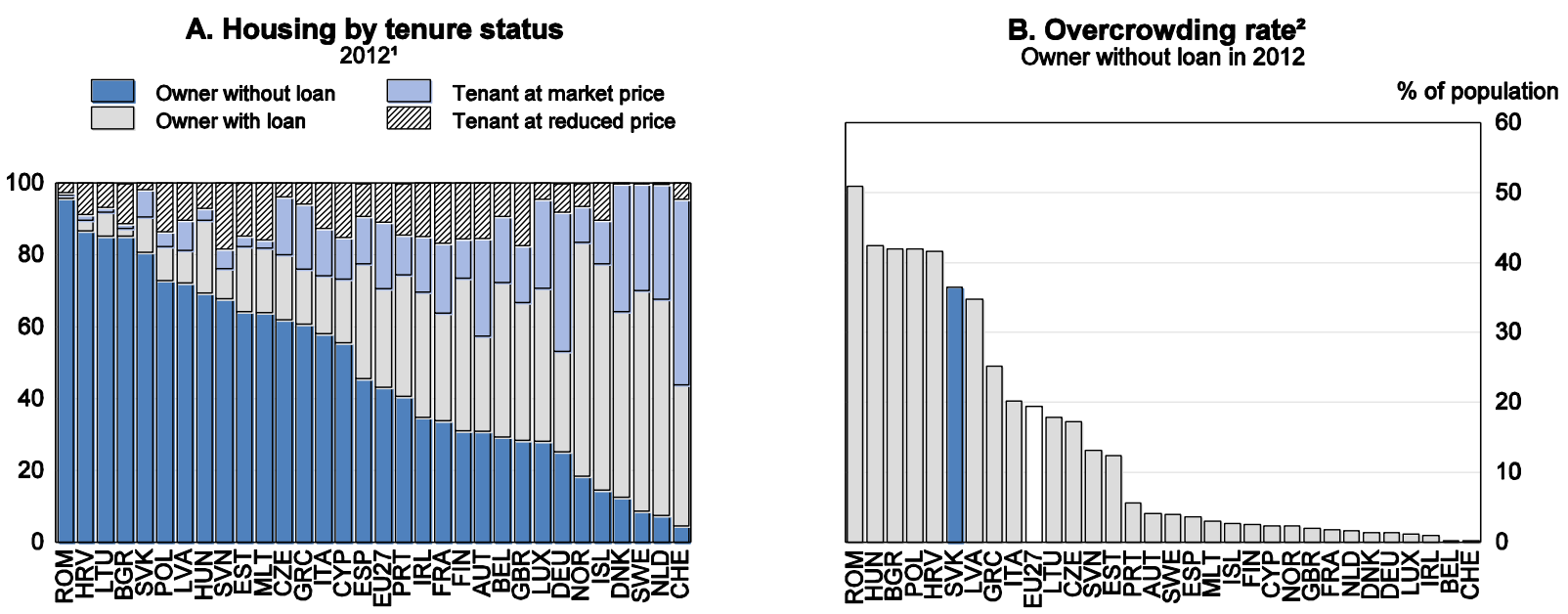

1. 2013 for Austria, Czech Republic, Finland, Hungary, Iceland, Latvia, Norway and Spain.

2. This indicator is the population living in an overcrowded household, i.e. without at its disposal a minimum of rooms. The definition of minimum rooms depends on the age and sex of the individuals living in the dwelling.

Source: Eurostat SILC.

\section{Public policies should further encourage the development of a rental market}

11. Public support is biased in favour of home ownership (Table 1). Support includes grants allocated to youth for housing purchases; a state bonus on saving devoted to housing purchase, and subsidised interest rate mortgages (Box 1).

Table 1. Distribution of public support between home ownership and rental housing

\begin{tabular}{lcc}
\hline \multicolumn{1}{l}{ Housing support in Slovakia (mil. EUR) } & 2006 & 2013 \\
\hline SFRB & 38.3 & 35.5 \\
$\quad$ Housing ownership & 94.3 & 12.7 \\
$\quad$ Rental housing & 23.5 & 106.5 \\
$\quad$ Restoration, insulation and other & 34.7 & 39.1 \\
State bonus within the "Housing Saving Scheme" & 21.6 & 31.0 \\
Mortgage subsidy for young & 70.9 & 23.9 \\
Social Rental Housing Subsidy (Act 443/2010) & 0 & 2.3 \\
\hline Substitute Rental Housing Subsidy (Act 261/2011) & $\mathbf{2 8 3 . 1}$ & $\mathbf{2 5 0 . 9}$ \\
\hline
\end{tabular}

Source: Ministry of Finance

12. Although the share of public support to rental housing has fallen (Table 1), some steps have been taken to promote rental housing. Under a recent regulation, loans with subsidised interest rates are provided to the private sector acquiring rental housing under the conditions that the house is rented for at least 30 years; it is rented to a low-income tenant and it is built close to an industrial park. In addition to municipalities and self-governing regions, NGOs are eligible for subsidies to provide standard rental 
housing for low-income households. Moreover, subsidies have been increased by 10 percentage points (covering $30 \%-40 \%$ of average costs against previously $20-30 \%$ ).

On the other hand, some broad based programmes provide home ownership public support:

- The Housing Saving Scheme that provides a state bonus to anyone who has saved at least EUR 781 has several drawbacks including that it is not income tested; the bonus can be used after six years for any purpose, and it distorts market competition as banks involved in it make extra profits by offering a lower interest rate than the market rate.

- The state subsidised mortgage and subsidised long-term loans provided for property acquisition by the State Housing Development Fund (SHDF) are regressive; they distort the allocation of resources; and they have perverse economic effects, in particular at a time of very low interest rates (Andrews et al., 2011).

13. The lack of support for renting, targeted at low-paid workers, adds to the problem as their income does not allow them to cover the cost of moving and inhabiting dwellings in most economically dynamic regions. In that regard, international experience suggests that housing rental allowances are preferred to social housing because they do not seem to hinder mobility as allowances are not tied to a home (ECB, 2003). Such a scheme exists in Slovakia but is weakly developed, with only very poor households entitled to social assistance benefits who are eligible (Hüfner, 2009). The authorities could consider extending it to poor households in general, including poor workers, as has been done in Ireland, the United Kingdom and some Nordic countries (Andrews et al., 2011).

14. Regulations covering rents and tenant-landlord relationships have a strong impact on rental supply. Rental regulation is close to the EU average. However, some specific characteristics of Slovak regulation reduce incentives to rent. In particular, landlords cannot evict a person without providing him appropriate alternative accommodation even if the notice reasons include serious damage of property or failure to pay rent (Vagac, 2013). Since May 2014, a short-term contract (maximum two years) can be established, with possible agreement on a shorter notice period or reasons for contract termination, including the non-payment of rent. This should be pursed further by allowing more flexibility for indefinite contracts and reducing their use in favour of extendible fixed-term contracts. Improvement of the efficiency of the judicial proceedings could also improve rental market potential (OECD, 2014d).

\section{Box 1. Housing market support in Slovakia}

\section{State Housing Development Fund (SHDF)}

In 2013, the total budget of SFRB reached EUR 155 million and the majority of the funds were devoted to insulations and restorations. Individuals can benefit from a subsidised long-term loan for property acquisition or reconstruction with a fixed interest rate for the whole period. The purchased flat or apartment should be new (2 years old or less), with a maximum area and the eligibility depends on age (less than 35 years old) and income (below 3.5 times the subsistence level, i.e. EUR 693 in 2014). The maximum loan amount is EUR 65000 and must not exceed $80 \%$ of the property value. Support is also provided to municipalities and legal entities for developing social rental housing.

\section{State bonus on saving}

Everyone who deposited at least EUR 781 in 2014 in the Housing Savings Scheme is eligible for a state premium of EUR 66. During the six first years of entering the scheme a condition applies on the use of the funds (for purchase or reconstruction of a property), but it disappears afterward, The state premium is not income-tested. 


\section{State funded subsidised mortgages}

People under the age of 35 are eligible for a subsidised mortgage with the interest rate reduced by $3 \%$ for five years if their income does not exceed 1.3 times the average wage of the last two quarters (for instance EUR 1043 at the beginning of 2014). The maximum loan is EUR 50000 and must not exceed $70 \%$ of the property value. Subsidised mortgages are also eligible for couples.

\section{Social Rental Housing Subsidy (Act No. 443/2010)}

A municipality, a self-governing region or an NGO are eligible for a social rental flats construction or purchase subsidy. Subsidies vary, according to the type of flat, from $30 \%$ to $70 \%$ of total construction costs. Built social flats must comply with maximum area requirements and rental status of the property must be kept for at least 30 years. To assure the social character, tenants are income-tested.

\section{Substitute Rental Housing Subsidy (Act No. 261/2011)}

Owners of restituted houses (returned to their original owners in 1990) have the right, according to 2011 legislation, to terminate a contract with tenants whose rent was regulated and substantially below market price. Tenants, usually older people living there for many years, have the right to ask a municipality for substitute housing and must leave the property before 2017 . For this purpose, the state subsidises mainly the construction of substitute housing, which should be ready by 2016.

\section{Housing allowance (Act No. 417/2013)}

Housing allowance is provided as a social support to persons in material need to cover housing-related costs. The support amounts to EUR 55.80 for a single person, for households with at least 2 members it equals to EUR 89.20. Eligible beneficiaries of the allowance have to be owners or co-owners of a dwelling, or tenants.

Improving the employability of low-skilled workers by stepping up active labour market policies

15. Low-skilled workers have job prospects that are worse than their counterparts in other countries. The employment rate of the low-skilled is only half that of the average observed in OECD, although that for the tertiary-educated is not significantly different (OECD, 2013b). Controlling for age and gender, failing to reach the upper-secondary level in Slovakia diminishes the employment rate by almost 30 percentage points (Figure 6).

Figure 6. Low skilled unemployment is the main challenge for Slovakia.
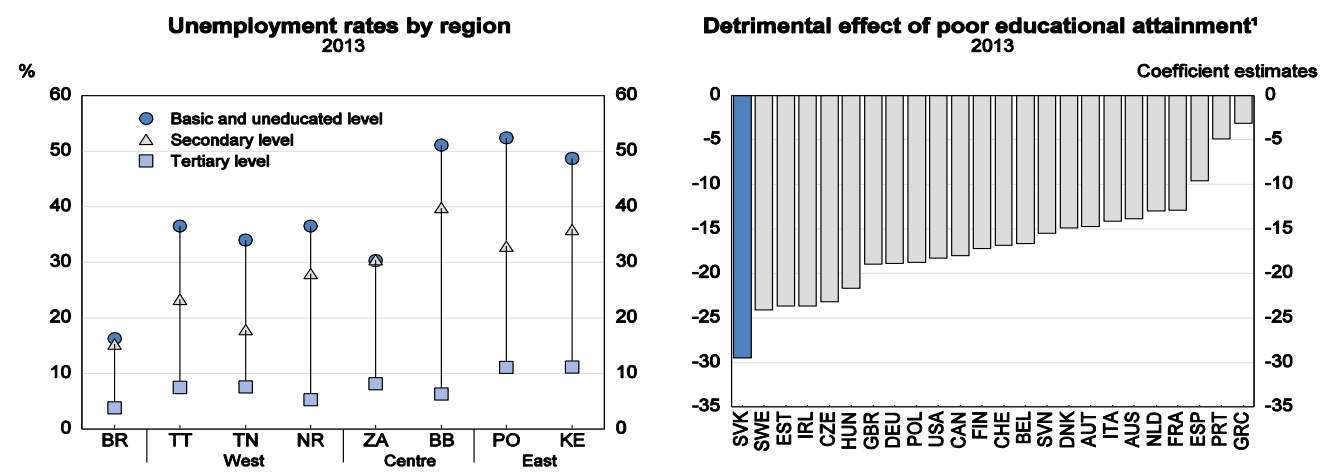

1. Primary and lower secondary education.

Note: Bratislava (BR), Trnava (TT), Trenčín (TN), Nitra (NR), Zilina (ZA), Banská Bystrica (BB), Presov (PO) and Kosice (KE).

Source: Statistical Office of the Slovak Republic; and OECD calculations (see for details the publication OECD Economic Surveys Poland, 2014). 
16. Regional disparities in low-skilled unemployment are also high; more than half of the lower educated (below upper secondary education) are unemployed in the east compared with less than $20 \%$ in Bratislava. To make the most of potential growth and to ensure a better integration with less-developed regions, addressing the challenge of the low-skilled is likely to be more important than expanding higher education (D'Costa et al., 2013; OECD, 2012a).

17. Tackling low-skilled unemployment requires efficient labour market policies at the national and regional level. As a first step, there is a need to increase overall resources devoted to ALMPs, especially in the east (OECD, 2012b). With $0.2 \%$ of GDP, spending in that area is the second-lowest among OECD countries. There is also room to make job-search support more effective, to refine activation policies, and to ensure that labour costs do not prevent low-skilled workers from being hired.

\section{Effectiveness of job search support could be raised}

18. Public Employment Services (PES), such as counselling and job search support, are the most effective programmes for reducing unemployment and, in particular improving labour market performances of low-skilled (Card et al., 2010; EC, 2013). They also contribute to maintaining labour market attachment and to providing information on job offers that may boost labour mobility.

19. However, the limited capacity of the PES hinders its effectiveness. With on average 187 unemployed per one labour office employee in 2013, the Slovak caseload is about twice as high as in other Visegrad countries (Figure 7, Panel A). The difference is even stronger when taking into account front-line local staff only (OECD, 2012b). While there is a strong need to increase resources, significant staff cuts were experienced in 2011. Eight hundred and forty new staff members will be hired in 2014 but they will mainly be in charge of new tasks related to the activation programmes of social benefit recipients (discussed below). The authorities should increase overall resources to PES to meet the demand created by high unemployment. Outsourcing part of job-search support activities to private providers, which the authorities are considering, could also supplement the weak capacity of PES (OECD, 2013c).

Figure 7. There is room for higher resources and efficiency in Public Employment Services
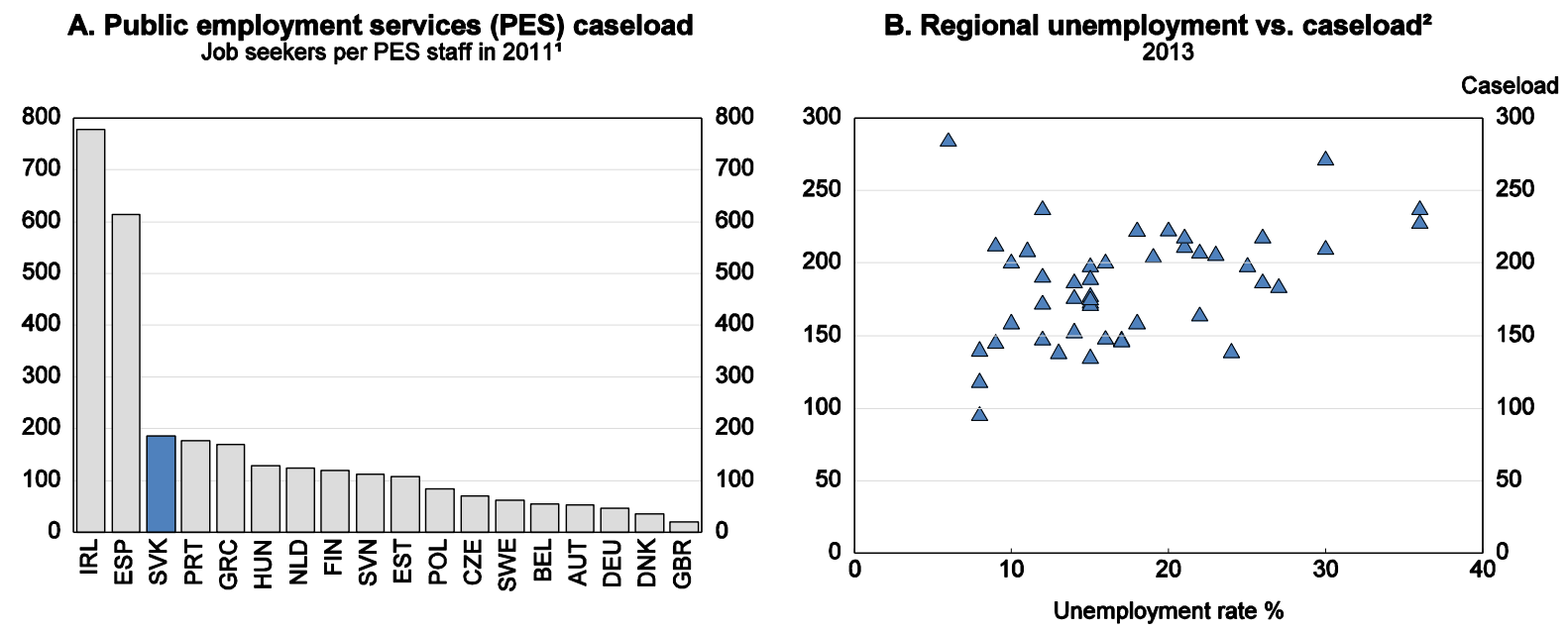

1. 2013 for Slovak Republic.

2. 46 labour offices of Slovakia. Bratislava is an outlier with a caseload of 285 and an unemployment rate of $6 \%$.

Source: PES staff numbers from European Commission, Employment, Social Affairs and Inclusion, Public Employment Services (http://ec.europa.eu/social/main.jsp?catld=105\&langld=en); Slovakia EK and Central Office of Labour, Social Affairs and Family. 
20. Unbalanced caseload distribution across the country adds to the problem. The caseload ranges from less than 100 unemployed for an officer in Pezinok to a peak of almost 300 unemployed per officer in Bratislava. While Bratislava could be viewed as an outlier with a large share of unemployment of short duration (Table 2), on average, labour offices with higher caseloads have to deal with high local unemployment rates (see Figure 7, Panel B). Efficiency and service quality gains could be achieved, therefore, by redistributing personnel based more on local needs.

Table 2. Duration of unemployment by region

Per cent

\begin{tabular}{|c|c|c|c|c|c|}
\hline & $\begin{array}{l}\text { Less than } \\
6 \text { months }\end{array}$ & $\begin{array}{l}\text { From } 6 \text { to } \\
12 \text { months }\end{array}$ & $\begin{array}{c}\text { From } 1 \text { to } \\
2 \text { years }\end{array}$ & $\begin{array}{c}\text { From } 2 \text { to } \\
4 \text { years }\end{array}$ & $\begin{array}{c}\text { More than } \\
4 \text { years }\end{array}$ \\
\hline Bratislava & 38 & 19 & 17 & 18 & 7 \\
\hline Trnava & 9 & 15 & 21 & 30 & 25 \\
\hline Trenčin & 29 & 23 & 18 & 19 & 11 \\
\hline Nitra & 18 & 11 & 15 & 28 & 28 \\
\hline Žilina & 23 & 17 & 17 & 19 & 24 \\
\hline Banská Bystrica & 15 & 7 & 16 & 15 & 47 \\
\hline Prešov & 18 & 8 & 17 & 22 & 36 \\
\hline Košice & 17 & 9 & 15 & 24 & 35 \\
\hline
\end{tabular}

Source: LFS 2013.

21. A comprehensive reform of PES that would enhance the quality and cost-efficiency of services is ongoing, in line with some recommendations made in the previous Economic Survey (Box 2). The reform is planned to be fully applied by 2020 and the government should consider accelerating the pace of its implementation. Key changes include (NRP, 2014):

- The individualised treatment of the unemployed has been strengthened by suppressing the mandatory meeting for each unemployed. This initiative brings additional flexibility and allows officers to focus on specific groups.

- The quality of services provided by employees depends on their skills and motivation. The national project "Improvement quality and accessibility of PES" aims to train about 2700 PES employees and to develop their IT skills.

- The future integration of job-search support and payment of benefits would also contribute to achieve efficiency gains (OECD, 2001).

\section{Box 2. Ongoing reform of public employment services}

The reform aims at increasing the flexibility, capacity and quality of services and should be fully implemented by 2020 .

\section{Strengthening the responsibility and autonomy of the Central Office of Labour}

The general directorate and branches of labour offices will be integrated in January 2014. The Central Labour Office will be fully responsible for the management of individual labour offices and their staffing. 
Integrating active and passive labour market policies

Labour offices will have responsibility for:

- $\quad$ Front-office tasks (professional first-contact services, applications and data processing, career counselling).

- $\quad$ Back-office tasks (job offers search and interviews, active labour market policies).

- $\quad$ Automatic payments processing of benefits.

Adapting the budget to local labour market needs

The budget of labour offices will depend on labour market needs (e.g. unemployment rate) and outcomes (e.g. number of job-seekers hired that remained in the job, adequate offer of ALMP programmes).

\section{Increasing motivation of public employment officers}

The existing financial remuneration of employees is below the average for public administration (80\%). Based on the outcome indicators, employees providing professional and information-counselling services will receive wages corresponding to the average wage in public administration.

\section{Monitoring ALMPs}

A central database of the labour market office was established and would allow monitoring of ALMPs by the Ministry of Labour, Social Affairs and Family and the Central Labour Office. A methodology for assessing the efficiency of active labour market measures was developed and approved by the Ministry of Labour in early 2012.

\section{Improving efficiency and modernising services}

A new web portal was launched in November 2013 which enhances back office IT system. It gathers job vacancies, implements matching of occupational classifications with clients' profiles, and provides services to inform clients about job vacancies.

Administration and bureaucracy in the PES have been lowered.

\section{Active labour market policies need to be refined to meet regional needs}

22. The May 2013 reform of activation policies has likely generated some efficiency gains by i) suppressing some redundant and ineffective programmes; ii) reducing administrative burdens when implementing programmes; and iii) establishing clear criteria for programme eligibility (age, qualification, duration of unemployment and local labour market conditions). There is still room for efficiency gains by re-allocating spending toward the most efficient programmes. The regional allocation of programme needs also to be refined to ensure that support reaches those in needs.

\section{Developing training programmes, and phasing out public works, especially in the east}

23. With only $1 \%$ of ALMP spending devoted to training, the resources devoted to such programme is insufficient insofar as it is one of the most efficient activation programmes according to international experience (Card et al., 2010). Training contributes to strengthening the employability of jobseekers by improving their ability to match labour market needs and raise the quality of the job that they obtained ex post. Training may also boost the mobility of workers by raising skills, since skilled workers are more mobile (OECD, 2005a). The authorities should consider allocating further resources in that area (Table 3). 
24. Training programmes are best developed in the west and Bratislava regions but are non-existent in lagging regions (Table 3). This contrasts with the objective of the May 2013 reform which strengthens the regional dimension when allocating actives policies. The authorities should monitor closely the regional allocation of training programmes to ensure that these programmes reach the most vulnerable in the east.

Table 3. Allocation of resources among activation programmes: national and regional

\begin{tabular}{|c|c|c|c|c|c|}
\hline \multicolumn{6}{|c|}{ Per cent } \\
\hline Year & Training & $\begin{array}{l}\text { Employment } \\
\text { incentives }\end{array}$ & $\begin{array}{l}\text { Direct job } \\
\text { creation }\end{array}$ & $\begin{array}{l}\text { Start-up } \\
\text { incentives }\end{array}$ & $\begin{array}{c}\text { Supported } \\
\text { employment } \\
\text { and } \\
\text { rehabilitation }\end{array}$ \\
\hline 2013 & 1 & 61 & 4 & 11 & 22 \\
\hline \multicolumn{6}{|c|}{ Region } \\
\hline Bratislava & 77 & 1 & 2 & 5 & 5 \\
\hline Trnava & 4 & 6 & 4 & 5 & 7 \\
\hline Trenčin & 2 & 11 & 5 & 10 & 15 \\
\hline Nitra & 1 & 11 & 8 & 12 & 12 \\
\hline Žilina & 7 & 14 & 7 & 13 & 13 \\
\hline Banska Bystrica & 6 & 15 & 22 & 16 & 16 \\
\hline Prešov & 1 & 23 & 17 & 19 & 16 \\
\hline Košice & 2 & 19 & 35 & 20 & 17 \\
\hline
\end{tabular}

Source: COLSAF.

25. The training design is essential for effectiveness. International experience suggests to $i$ ) promote market-oriented training, including in the workplace; ii) develop intensive programmes on a small scale (with high cost per head) rather than extensive programmes; and iii) provide some formal certification (Martin and Grubb, 2001; BIS, 2013). Some progress has been made regarding certification of skills and the recognition of non-formal education, and a new Act is under preparation (NRP, 2014) which could contribute to further mobility by allowing job seekers to have their skills recognised countrywide.

26. By contrast, public work programmes are not effective at improving employability (Card et al., 2010) and Slovak evidence confirms that it can even worsen the chance of future employment due to stigmatisation effects (Harvan, 2010). They hamper the mobility of workers as they tend to lock lowskilled workers into local job-creation schemes and they are used mainly in lagging regions, which contrasts with the need to promote labour mobility in those regions. Such schemes should therefore be phased out or targeted at the hardest-to-place jobseekers and made only temporary (OECD, 2009a). This could be for instance the case of long-term inactive people who need specific support to gain some work habits.

\section{Wage subsidies could be more targeted}

27. Active labour market programmes in Slovakia are mainly focused on wage subsidies (61\% of spending). While they are effective at bringing people into employment, they come with the risk of deadweight losses (hiring could have occurred even without the subsidy) resulting in only small net employment increases and a short-term effect (Martin and Grubb, 2001; Boone and van Ours, 2004; Kluve, 2010). Those schemes need to be closely targeted to provide a cost advantage to low productive workers who would not be employed otherwise, given their low level of productivity (Orszag and Snower, 2003). In line with this principle, wage subsidies schemes are more used in less-developed regions where low-skilled workers are over-represented (Table 3). 
28. Since November 2013, long term unemployed who have found a low paid jobs (67\% of average wage) under a standard labour contract, are exempted for 12 months from social security contribution paid by employees and employers (except accident insurance contribution and guarantee insurance contribution). By reducing the tax wedge, this scheme would raise incentives to work by increasing the net income of workers as well as the incentives to hire low-paid workers by reducing their labour cost (Figure 8). However, as of February 2014 it has supported only 1900 people, although 15000 participants per year were expected and the high share of long-term unemployed suggests a large potential. The authorities should closely monitor it to be sure that specific barriers do not hinder its use by employers. Going forward, the authorities should consider making this scheme permanent to ensure a lower tax wedge for low skilled. The current plan to exempt permanently low paid jobs (paid below 494 euros) from health insurance contribution goes on the right direction.

Figure 8. The tax wedge for low-paid jobs is high

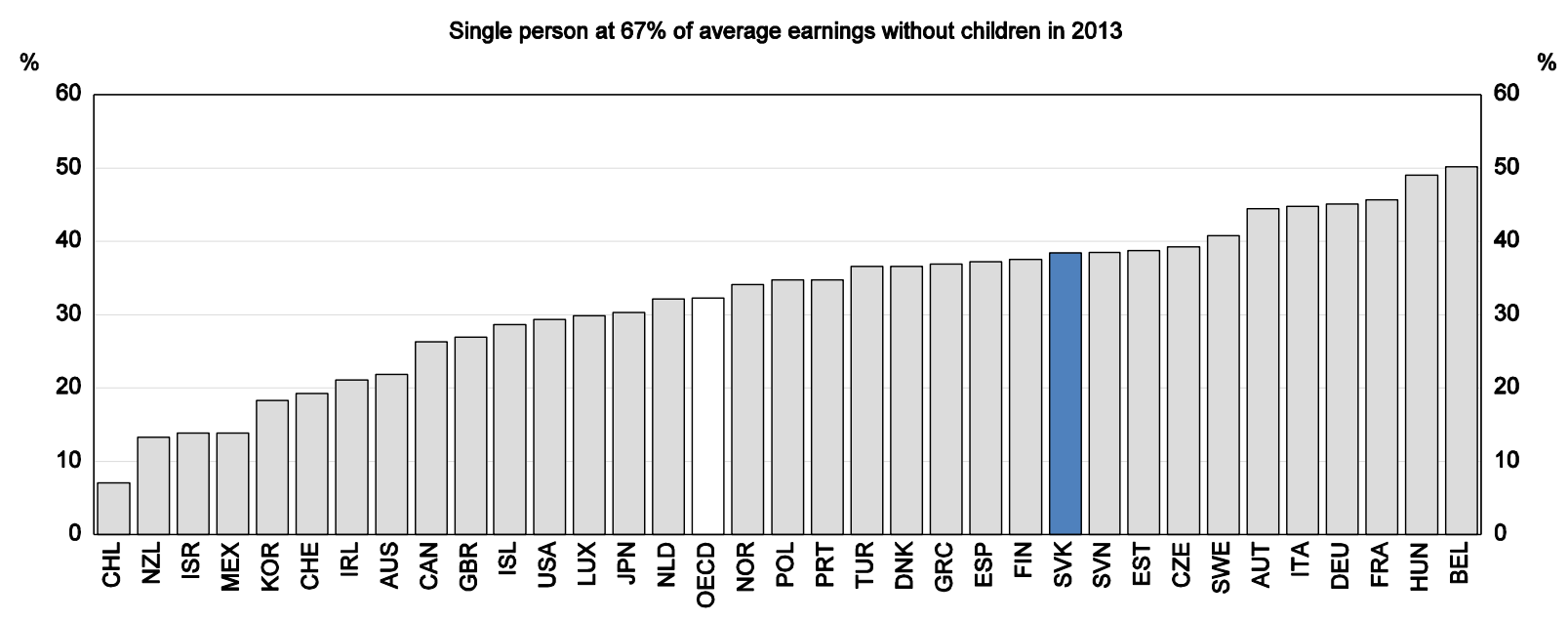

Source: OECD Taxing Wages Database.

29. There is also room to improve the efficiency of wage subsidies targeted at youth. The scheme "Supporting Job Creation" benefits youth under 29 without any conditions but having been unemployed for three months. This programme has been successful with 11500 jobs created since December 2012. However, it comes with the risk of high deadweight losses given the soft eligibility criteria. Without conditions on the level of education, employers might use this scheme to hire youth with better educational profiles who would have been hired in any case. This scheme should hence be reformed to be targeted at the most vulnerable youth.

\section{Start-up incentives have been reformed}

30. Start-up incentives have been reduced, in line with the recommendations made in the previous Economic Survey, and reformed to better adapt to local needs. Evidence regarding their effectiveness is mixed, notably because of the lack of entrepreneurial skills of some recipients (Martin and Grubb, 2001). Eligibility for those programmes is stricter since the May 2013 reform. The start-up incentive is also now provided in two stages: the first stage of $60 \%$ within 1 month after the conclusion of the agreement providing start-up incentives, the remainder after submission of a report after 12 months of selfemployment. In addition, the regional employment committee is now involved in the decision evaluating the effectiveness, efficiency and credibility of the business plan. This holds the promise of matching startups to local needs, but also adds another layer to the approval process. 


\section{Activation programmes for social assistance recipients could be refined}

31. Progress regarding the activation of social assistance recipients is mixed. New activation centers, under the responsibility of PES, were established in January 2014 and are responsible for activating recipients of benefits covering material needs. This goes in the right direction as international experience and in particular the Hartz-reforms implemented in Germany suggest that a more integrated approach of social policies and labour market policies would increase the prospect of recipients of social assistance benefits to find a job (OECD, 2010a).

32. An unattractive feature of the activation scheme is the mandatory work ( 32 hours a month in municipalities) imposed on recipients of material needs benefits. As discussed above, the effect of public work on future employability is limited: it may even be stigmatising in the labour market and reduce regional labour mobility. Stronger job search support and participation in activation programmes are preferred, such as training which contributes to raising skills and employability. Moreover, the activation programme could further contribute to regional disparities by increasing poverty for those who do not take a job and experience a cut in benefits. The authorities should therefore reconsider this measure. An alternative, more in accordance with international best practices, is to develop in-work benefits (OECD, 2005b). This helps promote social inclusion and employment by making work pay. Along this line, the authorities would consider providing stronger additional income support for low-paid workers and for recipients of material needs benefits engaged in training and educational activities.

\section{Containing labour costs increase in less-developed regions}

\section{Regionally differentiated minimum wage or social security contribution may be needed}

33. A minimum wage set at a high level can hinder employment prospects of the low-skilled by raising their labour cost above their productivity. The minimum relative to the median wage of the economy is at the OECD average and the share of employees earning the minimum wage is estimated at between $2 \%$ to $6 \%$ in Slovakia, which is close to the median value observed in European countries (Eurostat, 2010; INESS, 2013; Figure 9). However, the system is uniform across the country, and therefore may yield minimum wages that are too low in Bratislava but too high in the lagging regions, given sharp differences in market wages and living costs. Recent estimates confirm regional disparity as the share of minimum wage earners could be twice the national average in lagging regions such as Prešov and Banská Bystrica (INESS, 2013).

\section{Figure 9. Minimum wage needs to adapt to local labour market conditions}
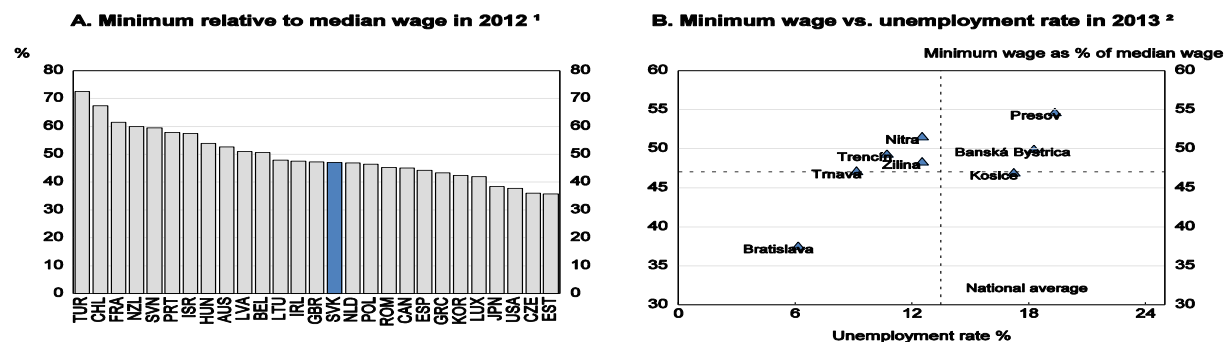

1. 2011 for Chile and 2013 for the Slovak Republic.

2. Data on median wage for 2013 are provisional.

Source: OECD Earnings Database and Statistical Office of the Slovak Republic.

34. The recent reform of the non-standard labour contract could make the minimum wage more binding for lagging regions. Until January 2013, a non-standard work contract ("work performance 
agreement") could be used by employers and was not subject to a minimum wage requirement or a social security contribution payment. They had been widely used, with 450000 individuals under those contracts in 2013, and their number decreased strongly after the reform (by 200 000). The authorities should carry out a study to assess and monitor the impact of the national minimum wage legislation on the labour cost and job creation in the eastern regions and explore the scope for measures which allow labour costs to respond to local conditions.

\section{The legal extension of collective bargaining should be reformed}

35. Collective bargaining agreements are important for improving working conditions and developing LLL of workers (Keogh, 2009), but an automatic extension to all firms impedes adaptation to Slovakia's widely varying regional labour market conditions. To improve the flexibility of wages and hours worked according to economic conditions, the employers had until January 2014 the possibility to opt out of collective bargaining agreements. While this option has been suppressed, employers have still the possibility to raise comments on the agreement at the Tripartite Commission, which can then decide to exempt them from the extension. The Ministry of Labour, Social Affairs and Family takes in particular into account a set of criteria before allowing an extension, including the representativeness of the agreement and the economic conditions of the sector (Box 3). Going forward, to ensure that extension of collective bargaining adapt to regional diversity, an option to consider is to establish transparent representation criteria before allowing for an extension agreement, as done in Portugal in 2011 when the authorities added the requirement that the employers subscribing to the agreements employ at least $50 \%$ of the workers in the relevant economic sector, in the geographic, firm size and occupation domains requested (OECD, 2012c).

\section{Box 3. Extension of collective agreements}

Collective bargaining in the Slovak Republic takes place at both the industry and company level. Legal extension has existed in the Slovak Republic since 1991, but was relaxed in 2004 by granting employers the effective right to veto an extension to their company.

Since 1 January 2014, any party to a higher-level collective agreement, negotiated between trade union organizations and employers' associations, may propose to extend the agreement to all other employers in the same industry. This extension may cover employers who did not participate in negotiations. The following conditions apply:

- $\quad$ Agreements at a higher level are superior to collective agreements at the company level and individual employment contracts. If higher-level collective agreements propose more favourable conditions for employees, employers must take them into account.

- It is not possible to extend a collective bargaining contract to other companies that are already covered by one collective agreement.

- The agreement can be extended only if it covers a larger number of employees in the industry than any other agreement.

- The government makes the final decision.

- $\quad$ Firms that employ less than 20 employees are not subject to extension.

\section{Aligning educational policies with employment objectives}

36. Regional disparities are also apparent in education, with Bratislava ranked 15th out of $265 \mathrm{EU}$ regions in terms of educational performance and the eastern region (Východné) ranked 211th (EU, 2012). 
Increasing the quantity and quality of education would improve employability of jobseekers in lagging regions where the low level of education is an important obstacle. Remedying this would raise productivity of workers make eastern and central regions more attractive for firms. Policies need to focus on improving the skills of workers, providing the employable skills for graduates and reducing inequality of opportunity.

\section{Improving the adaptability of workers through lifelong learning}

37. Lifelong learning contributes to improving labour market outcomes and productivity by raising the level of skills and improving matching. Empirical evidence suggests that a $10 \%$ increase of participation in LLL increases the probability of being active by $0.4 \%$ on average and decreases the probability of being unemployed by $0.2 \%$ (OECD, 2004; Bassanini et al., 2005). There are therefore significant gains that could be achieved by raising LLL in Slovakia, where only $3 \%$ of workers participated in LLL in 2013, compared with $10.4 \%$ on average in European countries, and where participation has even declined in the past few years, from 4.6\% in 2006 (Figure 10, panel A).

38. The low participation of workers in lagging regions adds to regional disparities (Figure 10, Panel B). Retraining workers make them more mobile across occupations and more adaptable to structural and technical change. It is hence particularly needed in eastern regions where occupational and regional labour mobility is low and the need for structural change high. The authorities should ensure that workers from less-developed regions participate sufficiently.

39. Market failures contribute to low incentives for companies and workers to invest in LLL, including: $i$ ) a lack of provisions in educational programmes; $i$ ) a lack of information about the rewards from training; iii) insufficient recognition of informal learning; and $i v$ ) the fear of poaching from other firms (Ok and Tergeist, 2003). Steps have already been taken by the authorities to promote LLL. Better recognition of informal education and training and the establishment of 25 counselling centres for adults should stimulate the incentives for employees. More could be done to support workers and companies financially with, for instance, vouchers which are effective at raising LLL participation (OECD, 2005c).

Figure 10. Lifelong learning is almost non-existent in lagging regions
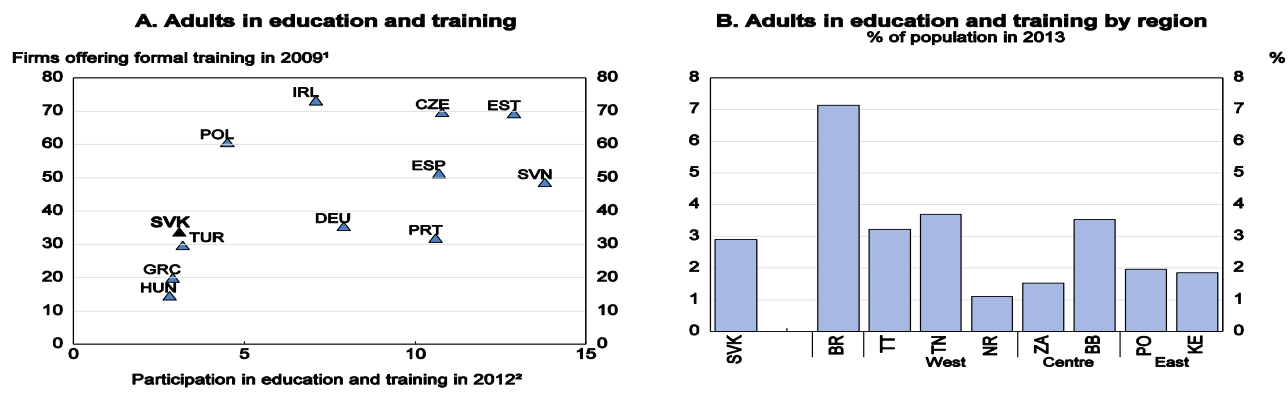

Note: Bratislava (BR), Trnava (TT), Trenčin (TN), Nitra (NR), Žilina (ZA), Banská Bystrica (BB), Prešov (PO) and Košice (KE).

1. Firms offering formal training programmes to their permanent, full-time employees. Data for 2008 for Turkey; 2005 for Germany, Greece, Ireland, Portugal and Spain.

2. Participation in formal and non-formal education and training by 25-64 year-olds. Per cent of population in same age group.

Source: Eurostat (2013), Population and Social Conditions: Lifelong Learning - LFS data; Eurostat Database, December; and World Bank (2013), Enterprise Surveys, www.enterprisesurveys.org.

\section{Ensuring a better matching of skills with labour market needs for vocational education}

40. Youth suffer from weak labour market, with an unemployment rate of 34\%, which is among the highest among OECD countries. The fact that about $19 \%$ of youth are not in employment, education or 
training (NEET) reflects poor school-to-work transition (Figure 11). This is even more striking in the east where the share of NEET is twice that of Bratislava (23\% against 9\%).

41. The vocational education and training (VET) system fails to provide adequate skills for the labour market (OECD, 2012b; Grubb, 1999; OECD, 2007). According to surveys from automotive industry employers, only $6 \%$ of secondary VET graduates are trained appropriately and ready for work (Cedefop, 2013). Weak school to work transition is notably due to insufficient cooperation between firms and VET schools, and has been identified by employers as an important barrier (PAS, 2013). The authorities have implemented some pilot projects, including apprenticeships, to tackle these challenges (NRP, 2014). Their expansion at the national level next year, with the objective of training 2000 youth in 2015 , is welcome. Special attention should be given to less-developed regions when implementing the new dual system and the allocation of resources across schools should take account of educational challenges. Currently Bratislava gets more resources in terms of teachers per 100 students (Figure 12).

42. The efficiency of the dual system to improve labour market outcomes for youth depends on the availability of sufficient workplace training of good quality. To provide sufficient incentives for companies, the authorities plan to exempt them from taxes. The authorities should accompany those schemes with strict quality control to ensure a balance between the skills acquired by the trainee, the productive work that she realises, the wage paid and the subsidy provided (Westergaard Nielsen and Rasmussen, 1999). Regionally differentiated support could be considered to increase incentives for firms to locate their activities in the east and central part and ensure that sufficient workplaces training are supplied.

Figure 11. Youth labour market performance is weak

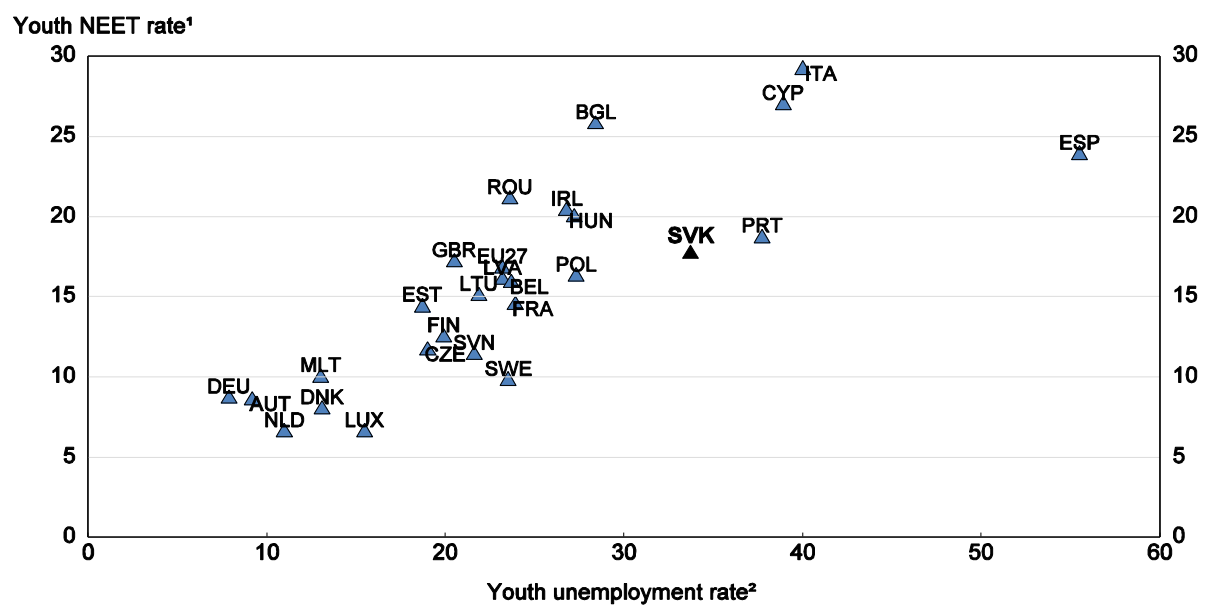

1. As a percentage of the population aged from 18 to 24 years.

2. As a percentage of the active population aged from 15 to 24 years.

Source: Eurostat 
Figure 12. Uneven resources of vocational education and training institutions should be avoided

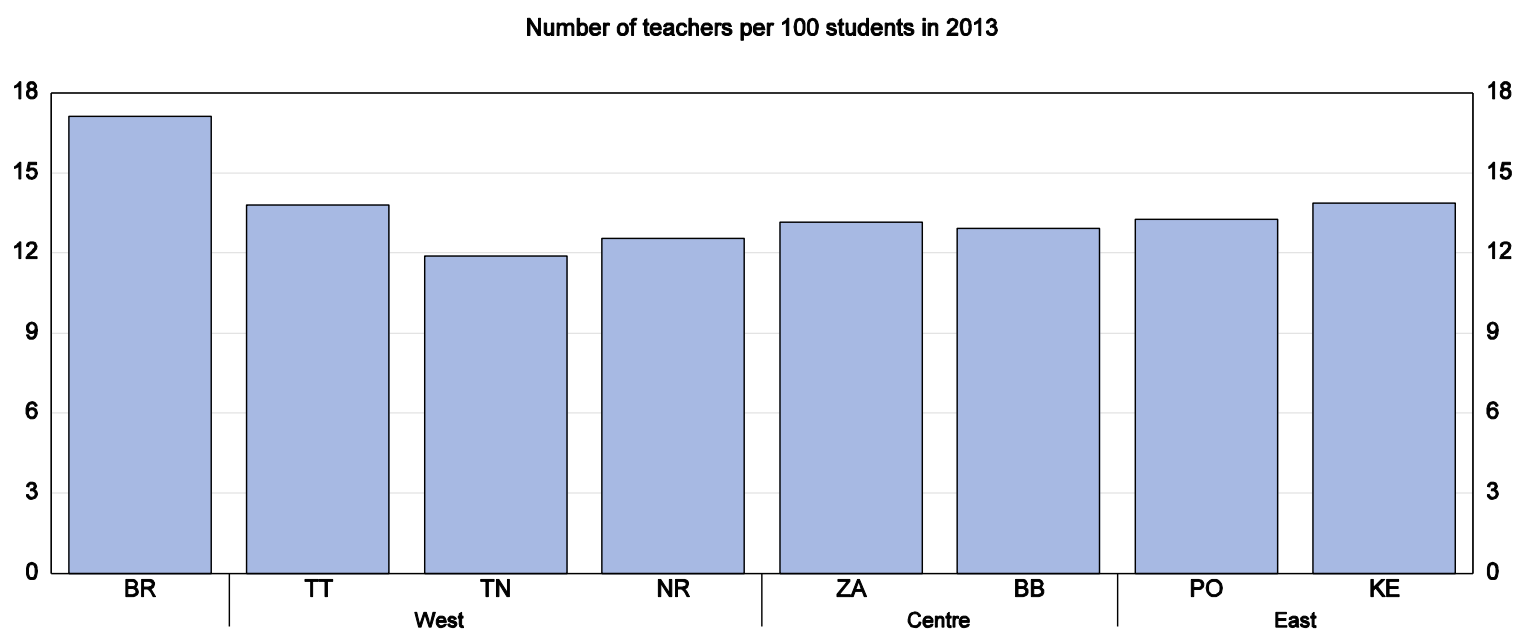

Note: Bratislava (BR), Trnava (TT), Trenčin (TN), Nitra (NR), Žilina (ZA), Banská Bystrica (BB), Prešov (PO) and Košice (KE).

Source: Staff calculation based on INEKO data.

43. Forecasting labour market needs and supporting areas with stronger potential for job creation is also essential for the success of the VET institutions. To that end, the authorities have set up a forecasting committee. In January 2014, a black list of redundant professions and a white list of dynamic professions with stronger jobs potential were identified. Those lists were supposed to be established based on unemployment rates of graduates following the two years of their graduation and the forecast of labour demand. Several drawbacks from the white list have been identified: 15 out of 39 professions from the white list did not have any graduates in the two past years, and 24 of them had an unemployment rate of $27 \%$. Given the public debate generated by this list, the methodology used should be made transparent and labour market experts involved.

\section{Raising the overall level of basic skills and increasing equality of opportunity}

44. The educational outcomes of students with low socio-economic backgrounds are among the worst in the OECD, a disadvantage that is even more striking in the east (Figure 13, Panel A; OECD, 2013b). Variation among schools appears much higher than what is observed on average in OECD countries, due to the poor performance of schools with a predominance of students with low social economic status (OECD, 2013d). 
Figure 13. Inequalities of opportunity in education are high
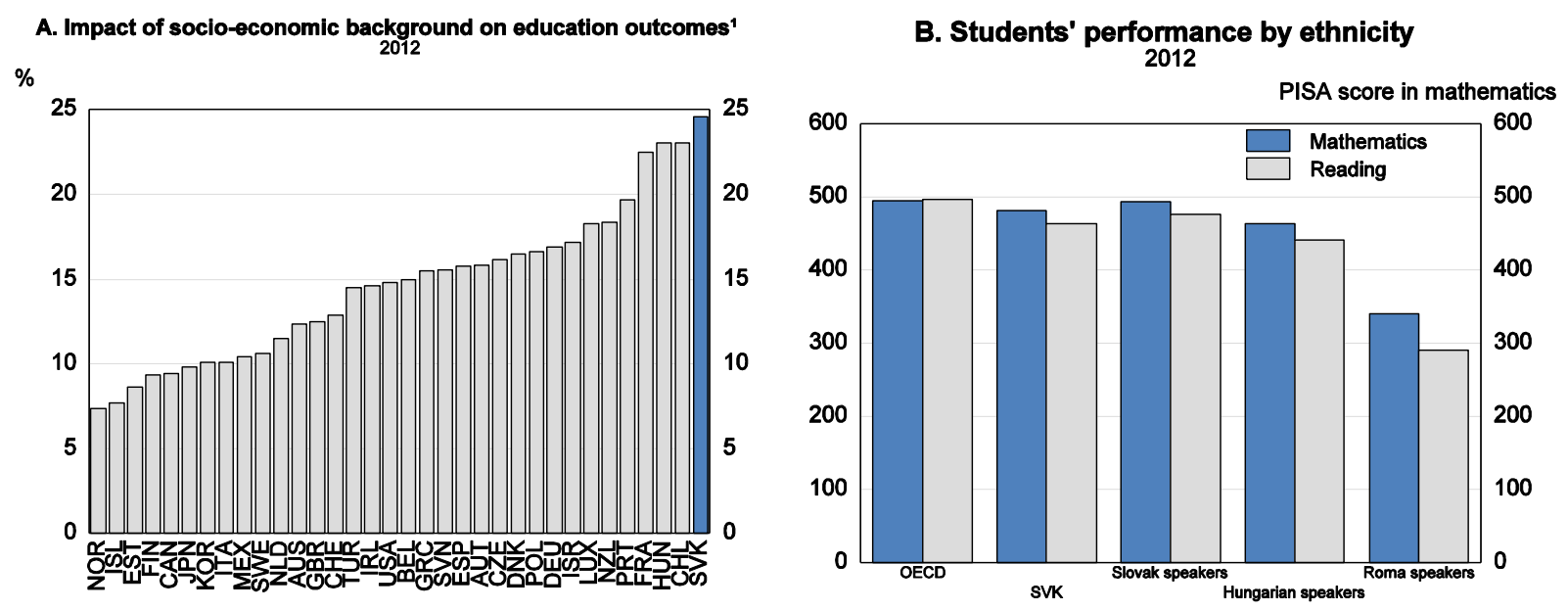

1. Percentage of variance in student performance explained by the Programme for International Student Assessment (PISA) index of economic, social and cultural status (ESCS), R-square*100.

Source: OECD (2013), PISA 2012 Results: Excellence through Equity (Vol. II).

45. International experience suggests that good quality early childhood education has a positive impact on future educational outcomes and reduces inequality of opportunity. Potential education gains from wider pre-primary education could be especially high in Slovakia; they are estimated at 40 additional PISA points, which is higher than OECD average (OECD, 2011b). However, Slovak participation in ECE is among the lowest in the European Union (77\% compared with $93 \%$ on average). For instance, in Belgium, Hungary, and the Netherlands, pre-primary education is nearly universal, with more than $90 \%$ of students reporting that they had attended pre-primary school for more than a year. This is in line with best practices in that area (OECD, 2011b). Suitable measures should be taken to raise the participation of children in pre-primary education, in particular those from poor socio-economic and Roma backgrounds, who tend to participate less (UNDP, 2012). Recent positive steps have been taken to develop the quality of pre-primary education and should be continued in line with the recommendations made by the OECD review on ECE quality (OECD, 2012e). The authorities plan to introduce by 2015 free pre-primary education for children aged over 3 years and from socially vulnerable groups, including the Roma children (NRP, 2014). This goes in the right direction and the participation rate should be closely monitored.

46. The motivation of teachers and teaching quality are also essential determinants of educational outcomes. Attracting the best teachers in schools where there are more students in need has proven to be effective. A recent increase in wages of teachers (by 5\% in 2013) goes in the right direction, but more is needed considering the Slovak gap; the wage of a teacher is about $44 \%$ of the average wage of tertiary educated individuals compared with $82-90 \%$ on average in OECD countries (OECD, 2013b). Further efforts should be made in that direction, including implementing a bonus for teachers teaching in schools where students with poor socio-economic backgrounds and Roma students are over-represented.

47. The poor educational outcomes of the Roma population, is a specific source of concern, as is their overrepresentation in special schools (see Figure 13, Panel B; OECD, 2012b; World Bank, 2012). Good quality early childhood education would reduce the probability of enrolment in special schools (World Bank, 2012). An alternative to mandatory pre-school education discussed above is to provide more in-kind benefits together with free pre-primary education for all children from the age of three. Financial incentives to parents of that sort have been provided for instance in Brazil with the programme Bolsa Familia targeted at primary-age school children (OECD, 2013e). The increase in the number of assistants 
("all-day project") should contribute to better integrating Roma pupils in standard schools by providing tailor-made support for integrating those students, including a Roma-speaking assistant. While support targeted at that population should be continued, the monitoring, implementation and evaluation of programmes is difficult in the absence of reliable statistics; these too should be developed.

\section{Improving transport and innovation infrastructures}

\section{The connection between lagging regions with the core economic centre needs to be improved}

48. Improving the quality and quantity of transport infrastructure is key to improve the development of lagging regions. Employers in the eastern and central regions view weak transport connections as the most significant barrier to regional development. (PAS, 2013). Regional differences of road density are large (Figure 14). Completing the transport infrastructure network in Slovakia will be both important for removing expansion bottlenecks in Bratislava regions and reducing obstacles for job creation in the eastern region.

Figure 14. Road infrastructure is insufficient
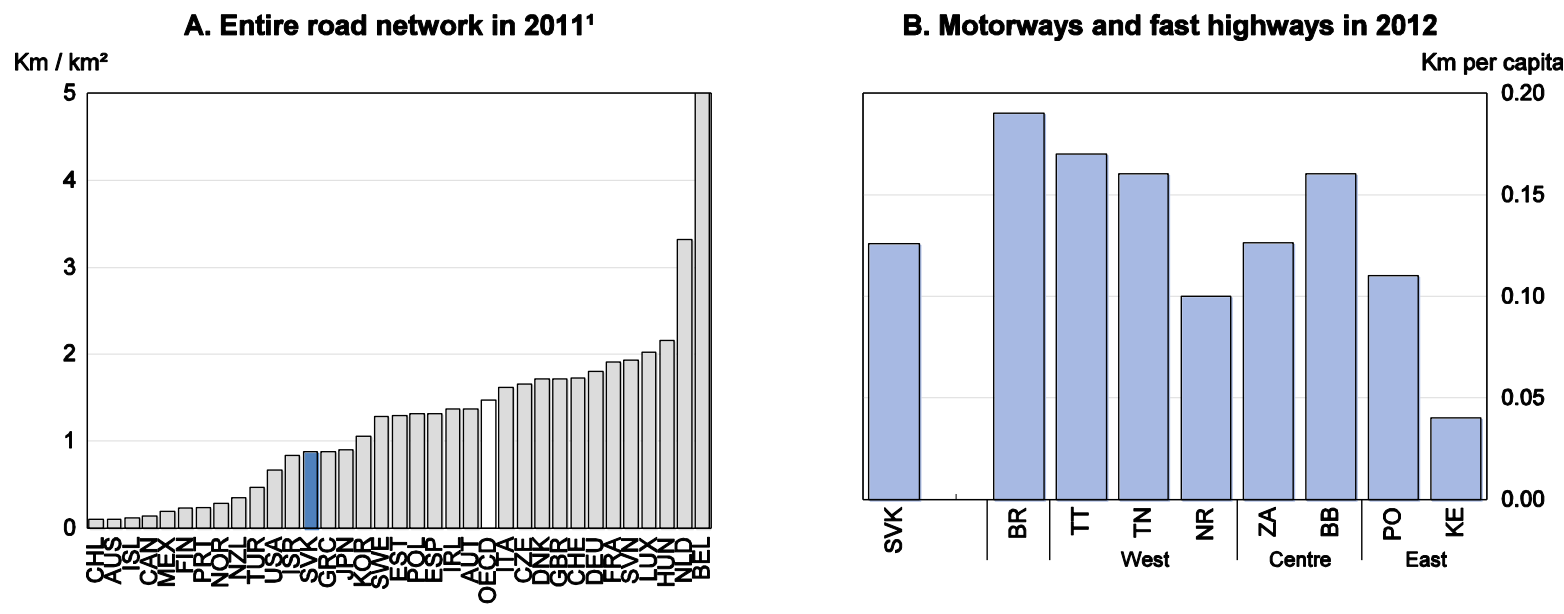

Note: Bratislava (BR), Trnava (TT), Trenčin (TN), Nitra (NR), Žilina (ZA), Banská Bystrica (BB), Presov (PO) and Košice (KE).

1. Road density is the ratio of the $\mathrm{km}$ length of the total road network per square $\mathrm{km}$. The road network includes all roads. Data refer to 2010 for Ireland, 2009 for Canada, 2005 for Italy and 2004 for Luxembourg.

Source: World Bank (2014), World Development Indicators (WDI); and Statistical Office of the Slovak Republic.

49. There is still no completed highway between the east and west. However a positive development is the fact that nearly all missing parts on D1 between Bratislava and Košice are now under construction. The road infrastructure between Kosice and Budapest and to Poland and Ukraine is also of poor quality (OECD, 2012a). Improving the availability of road infrastructure is a priority for the authorities, whose key objectives are to modernise first-class roads and to upgrade the road network, especially on corridors of the TEN-T network. Along those lines, the completion of the motorway D1 connecting Bratislava and Kosice is planned for 2019 and the connection with Poland and the Czech Republic is under construction. Other progress recently made include the finalisation of expressway between Košice and Hungarian borders and the preparation work on infrastructure projects towards the Polish and Ukrainian border. Such steps would contribute to growth (Sutherland et al., 2009) by reducing the currently large costs of access to Bratislava and to other EU countries (Dijkstra et al., 2011). 
50. Disputes related to public procurement decisions have been an important determinant of delays in road construction. The recent reform of the public procurement procedure should contribute to raising cost-efficiency of infrastructure investment as well as quality. Major aspects of the reform include a change in the selection process to strengthen quality-based decisions, the establishment of an independent Council of Public Procurement, and the establishment of a registry of reference to record the quality of providers (Box 4). While the reform goes in the right direction, its implementation is not fully effective and the procedure still appears lengthy, the use of e-procurement has declined and the number of complaints about decisions by the contracting authorities has not been reduced (EC, 2014). An effective implementation of this reform would also address the transparency challenges discussed in the Economic Survey of Slovak republic (OECD, 2014d).

\section{Explicit definition of extraordinarily low bid (ELB)}

- ELB is defined as a bid i) below $70 \%$ of the average of the other bids and; ii) below $85 \%$ of the second higher bid and; iii) below $85 \%$ of the expected bid. The procurer can exclude ELB from the competition if the clarification for the low price is not satisfactory or it is not provided.

\section{Establishment of a Council of the Public Procurement (PP) Office}

- It considers appeals against the PP Office's decision. Having the right to appeal is supposed to raise the quality of the PP Office decisions and to shorten the resolution of disputes by reducing claims brought to court, which has a lengthy resolution process.

\section{Creation of a registry of references}

- Upon the expiration of the contract, the procurer must issue a reference and grade the supplier. In the case of three subsequent references with very low grades, the supplier is suspended from all PP for one year.

\section{Simplified procedures for some procurement}

- It can be used for the procurement of legal services and in the case of low value. Previous experience with the bidder can be used as a criterion for the evaluation of the bids. The contracting authority is not obliged to award the contract to the bidder which has not made the best offer, to the extent that the awarded bidder is not more than $20 \%$ higher.

- The electronic marketplace can be used only for procurements below EUR 200000.

Others

- A new institute of ex ante review of public procurement documents has been introduced and is available only to "above-limit" contracts financed from European Union funds.

- Governments can ask the contractor to procure without PP in certain cases.

- Regulation of subcontracting: the law defines how much of the contract must be executed by winning suppliers. 
51. There are important barriers to road construction, including $i$ ) gaps in -compliance with EU rules regarding the implementation of impact environmental assessments; ii) irregularities in the declared costs submitted to the EC; and iii) inefficiencies in planning procedures (Box 5). A comprehensive reform of the public sector (OECD, 2014d) should address these obstacles, which would contribute to accelerating the pace of transportation infrastructure construction.

Figure 15. The quality of roads is weak
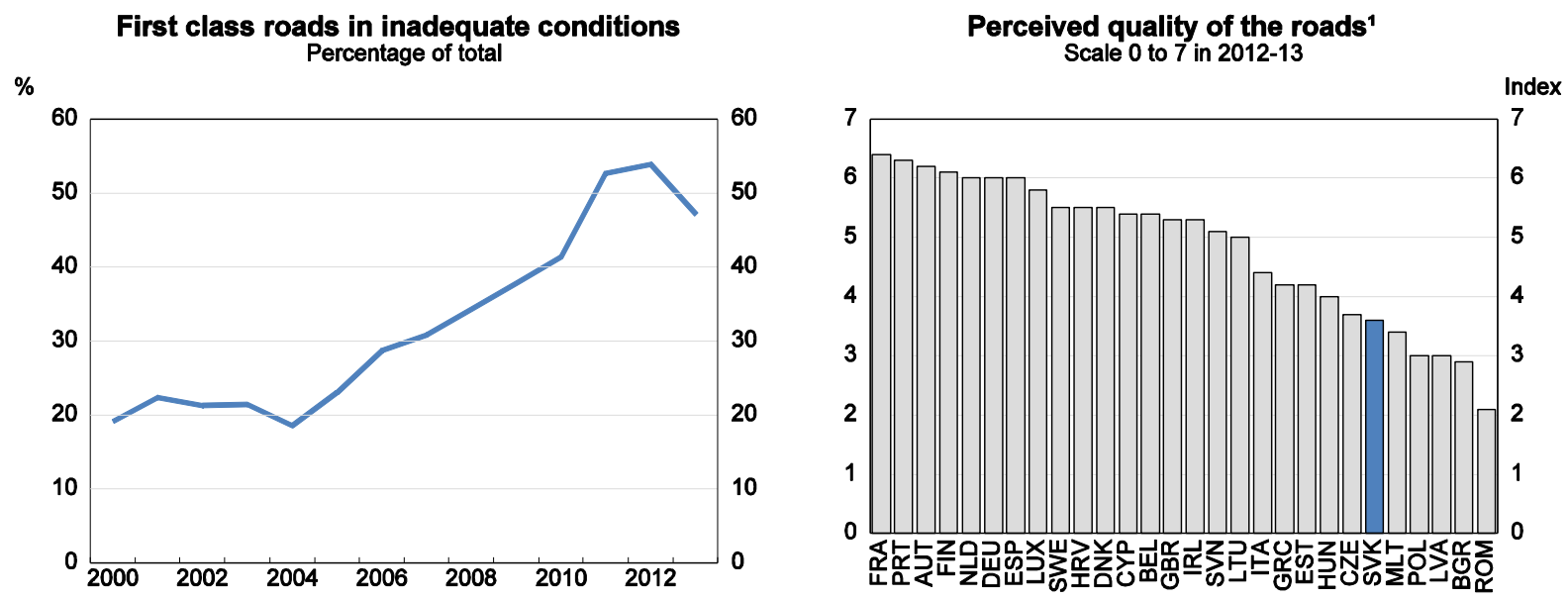

1. Weighted average. In your country, how would you assess the following aspects of transport infrastructure? Railroad system ( 1 = extremely underdeveloped among the worst in the world; 7 = extensive and efficient among the best in the world).

Source: Ministry of Transport, Posts and Telecommunications and World Economic Forum Executive Opinion Survey.

52. Specific attention needs to be paid to road quality, which is perceived as one of the lowest in the EU (Figure 15). First-, second- and third-class roads suffer especially from low quality while most of the motorways and fast highways are relatively new. The quality deterioration has peaked recently with half of the first-class roads labelled as in inadequate condition compared to less than $20 \%$ in 2010 . The trend is similar for second-class roads. Since 2014, the electronic tolling system charging trucks over 3.5 tons has been broadened to more first-class roads. This may have contributed to slowing down road degradation.

\section{Box 5. Main barriers that have slowed highway construction}

\section{Transparent public procurement}

Disputes regarding public procurement decisions have resulted in long delays in the implementation of projects, and in some cases bidders with very low prices were excluded. For example:

1) Svrčinovec-Skalité (D3): planned for 2012 but contracted only in June 2013;

2) Ruskovce-Pravotice (R2): planned for 2012 but contracted in December 2013;

3) Zvolen, východ-Pstruša (R2): planned for 2012 but contracted in July 2014.

Independent environmental and feasibility studies

The connection between Bratislava and the east has suffered from delays related to the treatment of the ecological impact of the planned highway on the sites that are part of the Natura 2000 ecological network. The Turany-Hubová connection (D1) was delayed for more than two years due to discussion between the commission and the authorities regarding the need for a new impact assessment that follows the EC methodology in that area. The Slovak authorities did comply. However a new evaluation is ongoing after the modification of the project. 


\section{Landownership process}

The process that requires purchase of land prior to the start of construction has slowed down the implementation of some projects: for instance, Čadca and Bukov-Svrčinovec (D3) initially planned for 2013.

\section{Administrative issues}

The EC's payments through Operational Programme Transport were suspended between August 2011 and June 2012 due to irregularities in declared costs submitted to the EC.

Changes in planning certificates have delayed the connection Žilina with Brodno-Kysucké Nové Mesto (D3), initially planned for 2013 .

Source: UVO; NDSAS; Roth (2012).

53. Development of rail transport could ease road transport and reduce emissions in the transport sector. Rail transport infrastructure suffers from obsolescence and depreciation. The non-operability of railways with other neighbouring countries is also a barrier to the development of freight transport (PUSR, 2011). The authorities specified investment priorities for 2014-20 and have recently paid increased attention to the electrification, interoperability and modernisation of tracks to accommodate higher speed trains, in particular on the TEN-T network (OECD, 2013f). High regulated railway access fees in Slovakia until 2011 have also contributed to enhancing road transport compared to rails. Their reduction to the EU average level in 2011 was an important step and should be continued, along with raising fees for using road transport (PUSR, 2011).

\section{Spurring technology adoption in lagging regions to increase competitiveness}

54. The resources devoted to research, development and innovation activities are weak in international comparison (OECD, 2013fg). Slovakia ranks 20th out of $27 \mathrm{EU}$ countries on EU innovation (EU, 2014). As a result, the technological capacity of domestic firms is weak and they are positioned in downstream activities in the Global Value Chain, involving mainly assembly or manufacturing of components. (OECD, 2013h). The attractiveness of FDI involving R\&D activities is also weak compared with peers (RIS3, 2013). Going forward, strengthening the innovation framework is a national challenge for drawing more benefits from globalisation.

55. The regional disparity adds to the challenge as knowledge-based resources are almost nonexistent in the eastern and central regions (Figure 16). This hampers the capacity of firms to use and copy technology, which may require researchers and engineers (Cohen and Levinthal, 1989). Along the same lines, empirical evidence suggests that knowledge transfers, and related productivity gains, depend on own resources devoted to R\&D (Van Pottelsberghe de la Potterie and Lichtenberg, 2001; Griffith et al., 2004). As a result, weak investment of private sector in $R \& D$ contributes to lowering the scope for productivity growth and the attractiveness of eastern regions for economic activity.

56. Given the weak innovation framework, public policies are essential to trigger the move towards a knowledge-based society in Slovakia. The Innovation Strategy has rightly identified a set of challenges to be tackled for more evenly balanced growth based on knowledge-based resources, including the need to strengthen public sector research, clusters, an R\&D tax credit scheme, venture capital, incubators, and to focus resources in specific areas of specialisation, which are related to local comparative advantages (RIS3, 2013). Some of those issues were discussed in the 2009 Economic Survey of Slovakia, and its main recommendations remain valid (OECD, 2009b). An additional element to be considered is the regional design and impact of public policies. Policies to support innovation are more critical in regions near the technological frontier while lagging regions should rather implement policies to support the adoption and 
imitation of new technology (OECD, 2012a). To promote regional convergence, attention should in particular be given to policies that stimulate the investment in R\&D and the supply of skills needed for innovation and technology adoption. Greater development of clusters would help strengthening technological transfers between firms and with universities and research centres.

Figure 16. Raising the capacity to absorb technology of central and eastern firms is needed

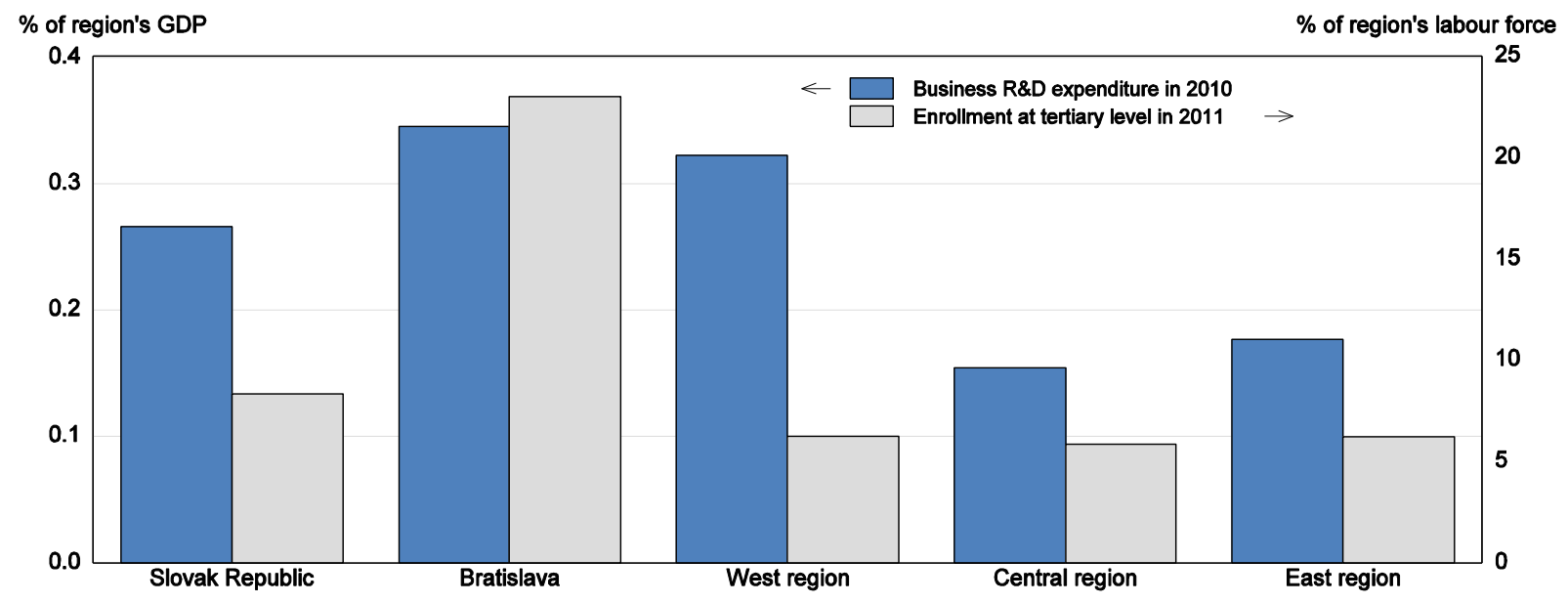

Source: OECD Regions and Cities Database.

\section{$R \& D$ tax incentives could be refined to further support technological adoption}

57. Public support for R\&D is low in international comparison (Figure 17). Horizontal tools, such as R\&D tax credits, are widely used by OECD countries as they tend to be more neutral and have more limited administrative burden than direct support (Andrews and Criscuolo, 2013). Substantial benefits could be achieved by raising and better designing such support. Empirical evidence suggests that reducing $\mathrm{R} \& \mathrm{D}$ costs through incentives by $1 \%$ would increase $\mathrm{R} \& \mathrm{D}$ by $1 \%$ in the long run (Westmore, 2013).

Figure 17. Public support to business R\&D is insufficient
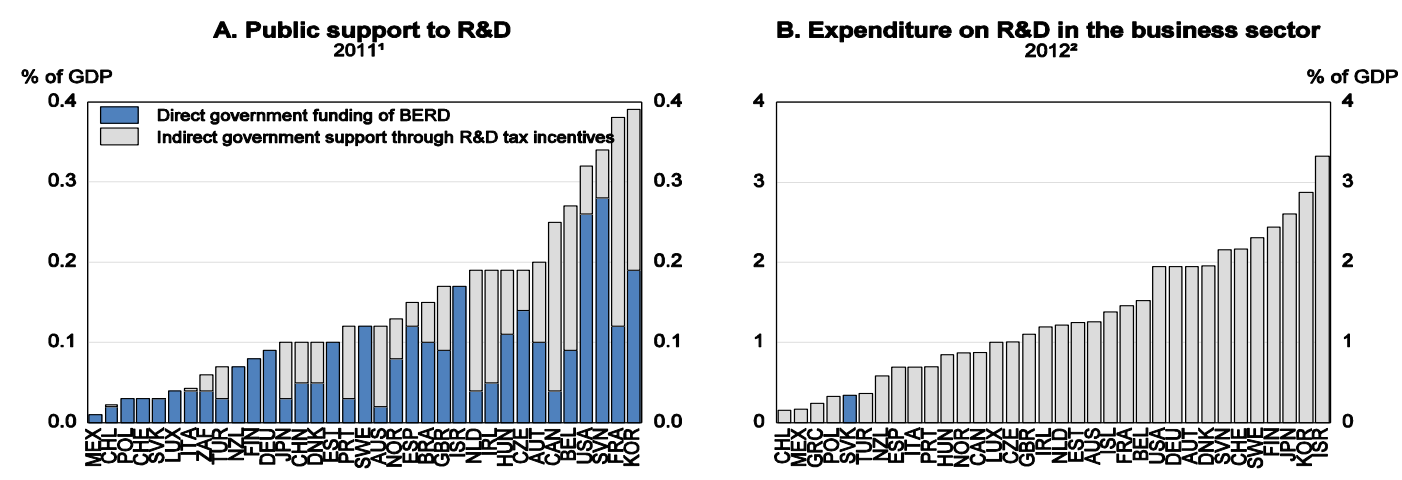

1. 2010 for Australia, Belgium, Brazil, Chile, Ireland, Israel and Spain, 2009 for China, Luxembourg and South Africa, and 2008 for Switzerland.

2. 2011 for Australia, Iceland, Japan, Korea, Mexico, New Zealand and Turkey, and 2010 for Chile.

Source: OECD (2013), Science, Technology and Industry Scoreboard and OECD Science, Technology and Patents Database.

58. The authorities have appropriately revised the R\&D tax credit. Slovak's R\&D tax credit was introduced in 2009 , allowing a firm to apply for tax relief. The tax relief is fixed at $19 \%$ of private R\&D 
spending - the level of the corporate income tax rate - and can be claimed for at most three consecutive taxation periods. This scheme, however, was not popular due to the imposition of a high threshold above which $\mathrm{R} \& \mathrm{D}$ costs are eligible. This level, which varies by firm size and the type of research, was substantial: in case of basic research (applied research), the lower limit was fixed at EUR 0.25 (1.5) million for micro and small, EUR 0.5 (2.5) million for medium and EUR 1 (3.5) million for large entrepreneurs. These criteria resulted in practice in the exclusion of a large majority of micro and small entrepreneurs, but were abolished in December 2013.

59. The design of $R \& D$ tax incentives is essential to contain fiscal costs and to achieve net effects (Criscuolo et al., 2009). R\&D tax incentives based on volume may have large deadweight losses when they support spending that would occur anyway (Andrews and Criscuolo, 2013). This kind of scheme tends also to mainly benefit to larger and incumbent firms. The authorities should consider implementing a hybrid scheme, including a tax relief based on the volume of $R \& D$ below a certain threshold and on the increase in $\mathrm{R} \& \mathrm{D}$ spending above this threshold. This incremental component would reduce the deadweight losses but comes with additional administrative burden (Andrews and Criscuolo, 2013) and requires significant steps to be taken regarding public sector efficiency (OECD, 2014d). The authorities could in particular consider the Irish experience, as the country has implemented such a hybrid system recently (Haugh, 2013).

60. The current R\&D tax credit scheme could also be made more effective in stimulating technological adoption in small and new firms. Firms, in particular young technological start-ups and SMEs, may not make profits the first years following their creation and hence cannot benefit from the support. To ensure that R\&D tax credits are effective, the authorities could make the tax credit directly refundable (OECD, 2013i). Other directions for reform favourable to SMEs are to make eligible the cost related to sub-contracted $\mathrm{R} \& \mathrm{D}$..

61. Even if $R \& D$ tax incentive schemes are refundable and contain carry-over provisions, young firms may not fully benefit from such schemes if they lack the upfront funds required to start an innovative project. Direct support is in that context complementary to tax incentives but needs to be well designed to reduce administrative costs (Andrews and Criscuolo, 2013). Such support can also act as a certificate of the quality of the investment that helps young innovative firms to access external financing (Busom et al., 2012). Finding a right balance between R\&D tax credits and direct funding will be essential.

\section{Professional higher educated students are needed}

62. Hiring more tertiary graduates is essential if firms in less-developed regions are to use new technology. However, in Slovakia only $19 \%$ of those aged 25 to 64 have attained tertiary education, compared with $32 \%$ in OECD countries. The picture is more favourable when looking at the share of tertiary graduates among the young generation, although the difference between Slovakia (26\%) and the OECD (39\%) remains the same. While this is still low in international comparison, the gap is expected to close as the demography of new graduates is more favourable in Slovakia (OECD, 2013b).

63. The tertiary vocational education programmes (type 5B) which focus on practical or technical education and provide occupation-specific skills designed for entry into the labour market are barely existent in Slovakia: in 2011 only 1.2\% of students are enrolled in such programmes against 13.2\% on average in the EU (EC, 2014). Developing short tertiary programmes, as currently considered by the authorities, that include on-the-job training and employable skills could provide the workers needed to use new technology. Such a programme should also include a robust level of general knowledge that provides students with the adaptive capacities necessary for technological change (Handel, 2012). While a new law on higher education is in the pipeline, the authorities should pay specific attention to this challenge. 


\section{Clusters could spur technological transfers}

64. Promoting relationships among firms and innovation actors could help spur technological adoption and innovation activities by creating a local labour market, taking advantage of the proximity of actors for ensuring diffusion of knowledge, and by using common infrastructure (OECD, 2011c, 2009c). Public policy can help public and private actors collaborate and share knowledge. For instance, promoting collaboration between university, industry and government has inspired cluster programmes in several OECD countries such as Finland, France, Norway and Sweden (OECD, 2008). The objective of those programmes is not to create clusters from scratch but to help latent clusters emerge and expand. Several clusters already exist relatively evenly spread throughout the country (Table 4).

Table 4. Regional distribution of clusters

\begin{tabular}{lccccc}
\hline \multicolumn{1}{c}{ Industry } & \multicolumn{5}{c}{ region } \\
BA & West & Central & East & Total \\
\hline Technology & 3 & 7 & 2 & 4 & 16 \\
Tourism & 0 & 2 & 5 & 2 & 9 \\
Hunting and forestry & 0 & 0 & 1 & 0 & 1 \\
Construction & 0 & 1 & 0 & 0 & 1 \\
Total & 3 & 9 & 8 & 4 & 27 \\
\hline
\end{tabular}

Source: Union of clusters (http://www.uksk.sk/) and the Slovak Innovation and Energy Agency (http://www.siea.sk/klastre-naslovensku/)

65. Innovation vouchers are successful instruments for promoting knowledge diffusion (OECD, 2011c). They give firms the opportunity to consult an innovation service provider of their choice who could help them identify and implement their technological projects. This can be particularly useful for SMEs who may face barriers in approaching research centres because of the small size of their projects. Moreover, innovation vouchers have the advantage of being more flexible than the current procedure of administrative selection of firms and the inherent difficulties picking winners. International experience suggests that a simple lottery or transparent eligibility criteria can be set out beforehand, in case the number of demand for vouchers is superior to the number of vouchers available (OECD, 2010b).

66. Cluster facilitators are critical to developing cooperation between firms (OECD, 2008). They notably take the form of individuals, private consultants or government agencies and their objective is to improve the conditions for cooperation. To that end, they can especially organise training activities, provide support services and promote a cluster (Ingstrup and Damgaard, 2012). They also support clusters as a whole when applying for public funds, in particular EU funds. The experience of the Klastry programme in the Czech Republic is of interest: it helps to develop sectoral competencies and networking, mainly among firms, in all regions outside of Prague with support from EU structural funds. Providing training and information to cluster facilitators would also contribute to strengthening existing clusters.

67. Launching competitive selection processes to allocate funds to the best organised clusters could also help to support excellence. Such programmes have been developed in Sweden (VINNVÄXT) and France (Les pôles de compétitivité). They are also extended to lagging regions such as the InnoRegio programme in Germany. International experience allows identifying best practices to assess the quality of clusters that could help authorities to implement similar schemes (Kocker and Rosted, 2010).

\section{Improving coordination among authorities in innovation policies}

68. Co-ordination and co-operation are essential to make the most of investment, to better cater for local needs and identify investment opportunities and bottlenecks (OECD, 2014a and 2013j). There is room for progress regarding the coordination and cooperation between the different institutions as 
discussed in the Public Governance Review of Slovakia (OECD, 2014b) and the Economic Survey of Slovak Republic (OECD. 2014d). Coordination between regional and central authorities is also essential in designing and implementing innovation policies. For instance, in Slovakia, the Smart Specialisation Strategy has been implemented only at the national level while it was meant to be based on selfidentification of regional and local comparative advantages. This is explained by the small size of the country and the weak technical capacities of regions. However, the smart specialisation strategy in France demonstrates that technical capacity can be centrally provided and combined with regional ownership, which has led to an improved assessment and consistency across regions (OECD, 2008). The case study launched in Východné Slovensko in June 2014, aim at applying the OECD principles on Effective Public Investment across levels of Government (OECD, 2014a) and would also help identifying key remaining bottlenecks to local investment.

\section{Making the most of EU funds}

69. Slovakia is among the main beneficiaries of EU funds which represent a substantial source of Slovak public funding (Figure 18). Over the 2007-13 programming period, EU funds for Slovakia reached EUR 11.6 billion. This amount is equivalent to the level of public investment. In the next programming period (2014-2020), the amount of EU funds allocated to Slovakia will increase to almost EUR 14 billion, i.e. almost $20 \%$ of GDP in 2013 (Figure 18). In terms of funds received per capita, Slovakia is the second main beneficiary of EU funds, following Estonia. EU funds offer Slovakia a great opportunity to tackle its regional disparity problem while strengthening the development of the country as a whole.

Figure 18. Slovakia is a main beneficiary from EU cohesion and structural funds in 2014-20

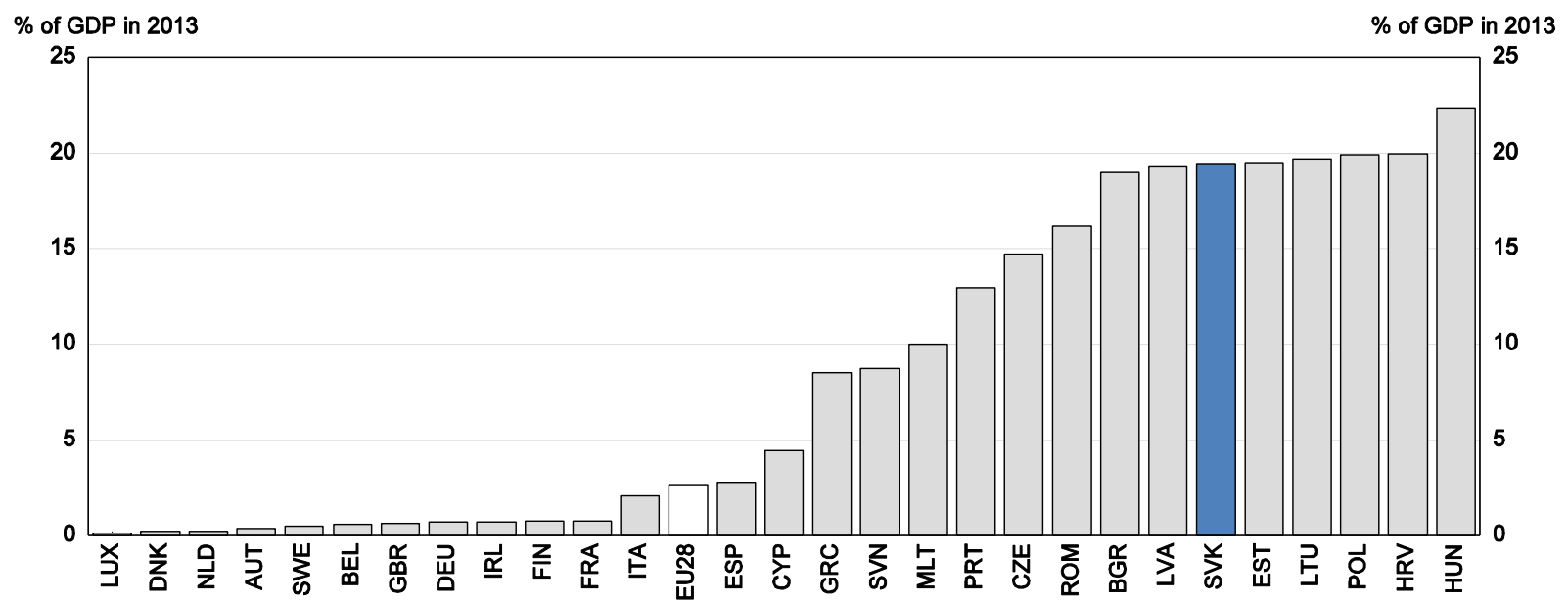

Source: DG Regio (http://ec.europa.eu/regional_policy/index_fr.cfm) and Eurostat.

70. The impact of EU funds for future growth depends on their efficient absorption and implementation, including at the regional level. Institutional barriers in the previous programming period included $i$ ) the administrative burden, ii) the lack of administrative capacity, iii) the lack of transparency in project selection and public procurement, $i v$ ) corruption, and $v$ ) the insufficient involvement of regional authorities (OECD, 2014d). To strengthen the impact of EU funds on regional convergence and better use them in line with local needs, poorer regions should receive a greater portion of the EU funds and regional authorities be more involved in the design of programmes. 


\section{There is room to strengthen the impact of $E U$ funds on regional convergence}

71. Devoting a larger share of EU funds to poorer regions is essential to promote regional convergence. In theory, the allocation of funds across the Slovak regions is meant to favour less developed regions. Accordingly, during the 2007-13 programming period, the Bratislava region was expected to receive about one third of the average funding of the other three regions in per capita terms, but contracted funds were similar in all regions (Figure 19, Panel A). In the next programming period, the difference between the Bratislava region and the other regions is supposed to be stronger; the per capita funds planned for all regions but Bratislava have increased on average by one fourth, and those planned for the Bratislava region decreased by $8 \%$.

72. Regional operational programmes (OPs), also play a critical role in tackling regional disparities given that the main factors constraining growth may vary considerably among regions at different levels of development (D'Costa et al., 2013). Moreover, such regional programmes are less subject to a reallocation of funds between regions (Figure 19, Panel B). However, they are insufficiently developed in Slovakia where there are nine sectoral but only two regional OPs, representing only $13 \%$ of the all received EU funds (Table 5). Other Visegrád countries operate separate regional OPs for each of their regions. No changes are planned in that regard in the next programming period.

Figure 19. Lagging regions tend to receive less EU funds than planned

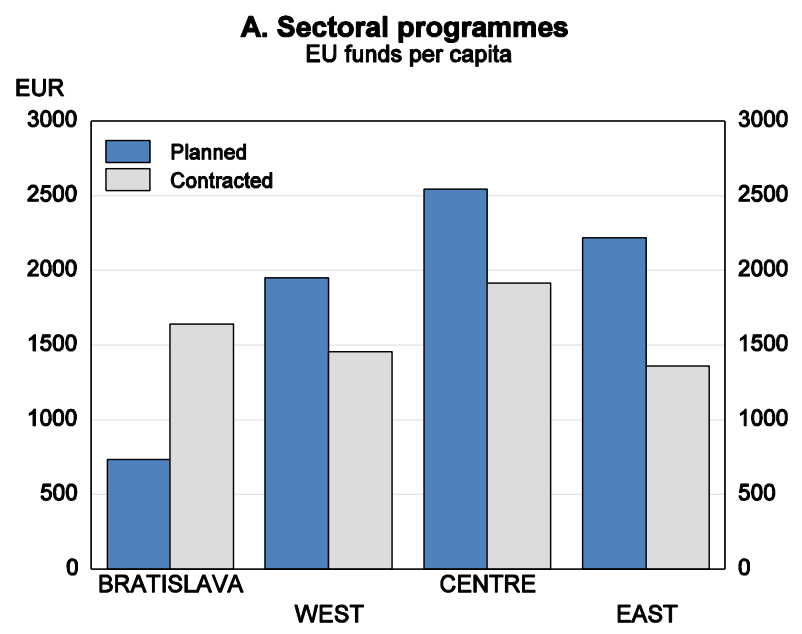

\section{B. Regional programmes}

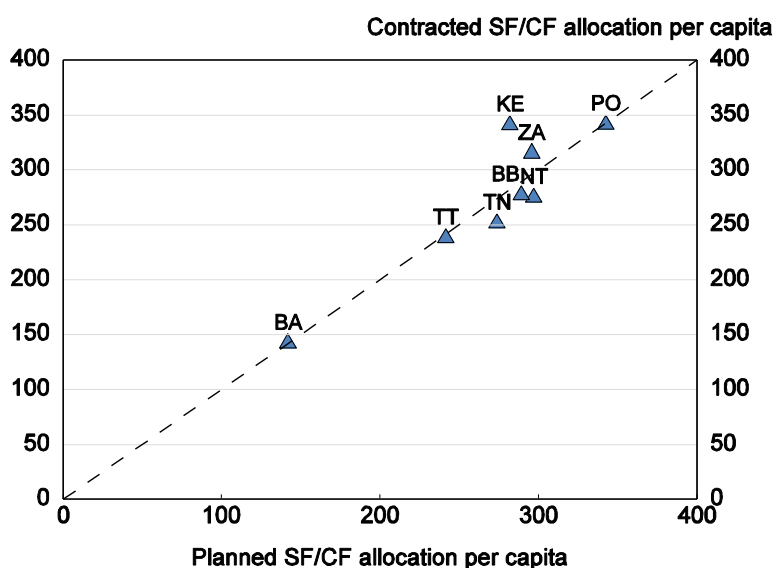

Source: National Strategic Reference Framework and Regional Operational Programmes.

Table 5. Share of EU funds allocated to regional programmes

\begin{tabular}{cccc}
\hline Poland & Hungary & Czech Republic & Slovakia \\
\hline $25 \%$ & $23 \%$ & $19 \%$ & $13 \%$ \\
\hline
\end{tabular}

Source: National Strategic Reference Framework 2007-2013 (EC, 2008; MDVRR, 2007)

73. Further involving regional authorities in the the design of programmes would increase the likelihood that funds match with local needs. During the 2007-13 programming period, self-governing regions were not involved in the preparation stage of the regional OPs because of their lack of capacity (Bucek, 2011). They became involved afterward once their capacity improved through technical assistance (MPRV, 2011). In the next programming period, the particular needs of each region will be addressed 
through regionally integrated strategies that will be designed by the self-governing regions in co-operation with other regional partners. Self-governing regions will be also responsible for the selection of projects under the Integrated Regional Operational Programme. Such an initiative goes in the right direction and should be continued while providing further technical assistance to regions to develop their capacity.

\section{The allocation of funds among priorities is consistent with the main Slovak challenges}

74. Priorities of cohesion policy of Slovakia for the 2014-20 programming period are in line with main challenges identified in this survey for spurring growth throughout the country: $i$ ) infrastructure for economic growth and jobs; ii) human capital growth and improved labour market participation; iii) innovation-friendly business environment; $i v$ ) modern and professional administration; and v) sustainable and efficient use of natural resources. Transport infrastructure development will continue to receive the largest proportion of the funds (MoF, 2014). Support for Innovations and R\&D will increase by $50 \%$ which will bring it to the level of other Visegrád countries in the 2007-13 programming period. The development of the ICT infrastructure remains a priority, which is in line with the plans to expand egovernment services (MoF, 2014; MV, 2014). The funding support to employment is, rightly targeting long-term unemployment, labour mobility and young people's integration into the labour market (MPSVR, 2014). It was raised by four percentage points, but it remains low in comparison with other European countries. A source of concern is the decline in the share of funds allocated to employment and innovation programmes, although they are identified as essential challenges for improving employability and productivity of workers, together with attractiveness of the country for investment (Figure 20).

Figure 20. Sectoral allocation of EU funds are in line with growth challenges

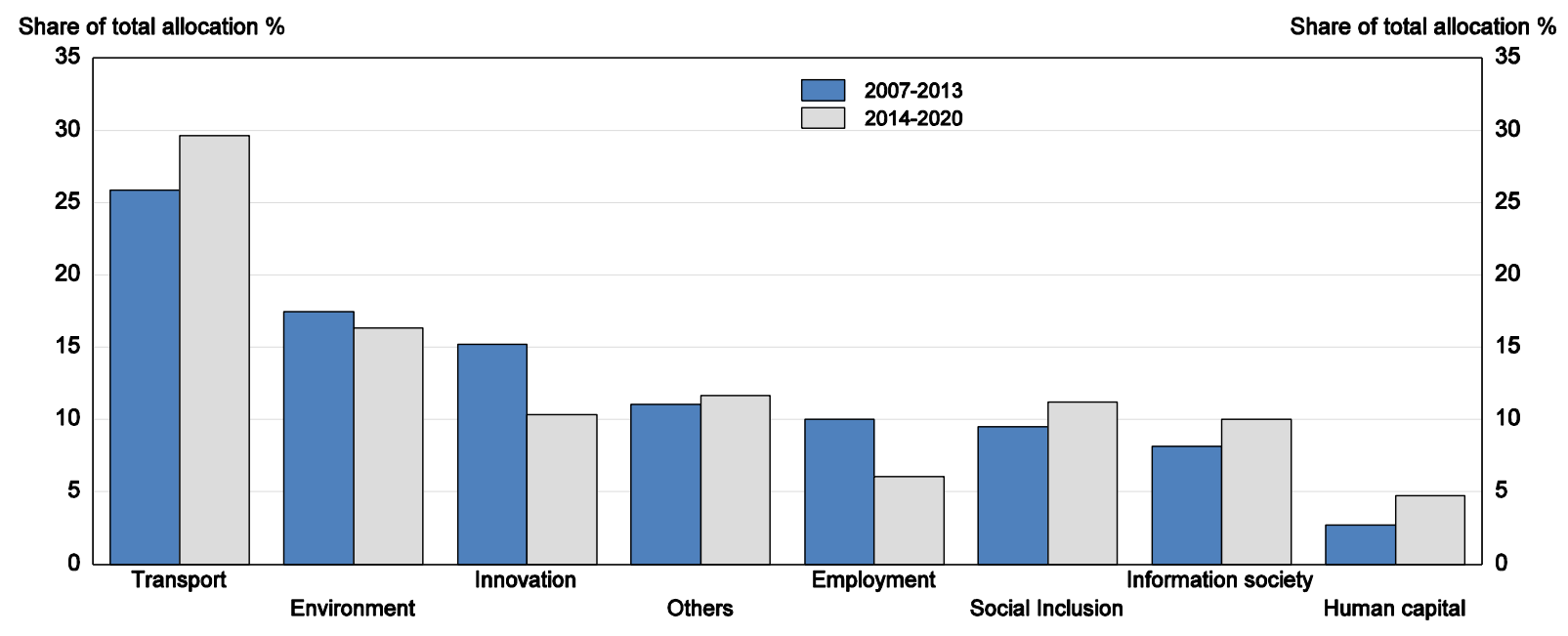

Source: DG Regio and Operational programmes for programming period 2014-2020. 


\section{Recommendations for spurring growth in lagging regions}

\section{Key recommendations}

\section{Boost the capacity to adopt new technology and reduce transport barriers}

- $\quad$ Develop professional tertiary education and support for cooperation with employers.

- Provide financial incentives for adopting new technology and innovation spending.

- Improve national road and rail transport infrastructure and international connections.

\section{Strengthen mobility and employability to reduce unemployed and inactive labour}

- To develop the rental housing market, phase out support to home ownership and expand means-tested rental housing allowances.

- Develop training as well as job-search support and phase out public works programmes.

- Make sure minimum wages and legal extension are implemented without damaging employment prospects, especially in lagging regions

\section{Reduce skills mismatch and better integrate disadvantaged groups, especially the Roma population}

- Implement a dual vocational education and training system and give specific attention to school-to-job transition in eastern regions.

- Develop the provision and quality of early childhood education and ensure wide access to low socioeconomic background children, especially Roma children

\section{EU funds}

- Provide the poorer regions with a higher share of EU funds and a stronger role in the design of programmes.

\section{Further recommendations}

\section{Housing}

- $\quad$ Suppress grants allocated to youth for housing purchases; the state bonus on saving devoted to housing purchase, and subsidised interest rate mortgages.

- $\quad$ Allow more flexibility for rental contracts and develop the use of extendible fixed-term contracts.

\section{Labour Market}

- Increase the overall resources devoted to activation programmes and public employment services (PES). Reallocate resources across PES offices according to local unemployment rates. Accelerate the pace of implementation of PES reform. Outsource part of job-search support activities to offset weak capacities.

- Narrow the eligibility of wage subsidies to youth. Make permanent the reduction of tax wedge for low-paid jobs. Suppress the mandatory work in municipalities for social assistance recipients. Make work pay by implementing in-work benefits.

\section{Education}

- $\quad$ Establish training vouchers to boost participation in Lifelong Learning.

- Implement financial incentives, such as tax deductions, for offering apprenticeships, with strict quality control.

- Develop statistics to monitor the effectiveness of support to the Roma population. 


\section{Transport and Innovation}

- Ensure the effectiveness of the public procurement reform.

- Develop innovation vouchers and reform R\&D tax credit to make it refundable. Promote cluster facilitators and a competition-based funding process.

- Provide technical assistance to regional authorities to develop capacities such that they can be involved further to assess and steer innovation policies at the regional level.

\section{BIBLIOGRAPHY}

Ahrend, R. et al. (2014), "What Makes Cities More Productive? Evidence on the Role of Urban Governance from Five OECD Countries", Regional Development Working Papers 05, OECD Publishing.

Andrews, D. and Ch. Criscuolo (2013), "Knowledge-Based Capital, Innovation and resource Allocation", OECD Working Papers 1046, OECD Publishing.

Andrews, D., A. Caldera Sánchez and Å. Johansson (2011) "Housing Markets and Structural Policies in OECD countries", Economics Department Working Papers 836, OECD Publishing.

Banerjee, B. and M. Jarmuzek (2009), "Anatomy of Regional Disparities in the Slovak Republic", IMF Working Papers 09/145.

Bassanini, A. et al. (2005), "Workplace Training in Europe”, IZA Discussion Papers No. 1640.

BIS (2013), "Youth Unemployment: Review of training for Young people with low qualifications", BIS Research Papers 101.

Boone, J. and J. C. van Ours (2004), "Effective Active Labour Market Policies”, IZA Discussion Papers.

Buček, J. (2011), "Building of regional self-government in Slovakia: the first decade”, Geographical Journal, 63 1, 3-27.

Busom, I., B. Corchuelo and E. Martínez-Ros (2012), "Tax Incentives and Direct Support for R\&D: What Do Firms Use and Why?", Business Economics Working Papers id-11-03, Universidad Carlos III, Instituto sobre Desarrollo Empresarial "Carmen Vidal Ballester".

Card, D., J. Kluve and A. Weber (2010), “Active labour market analysis policy evaluations: a meta analysis”, Economic Journal 120.

CECODHAS (2012), The Housing Europe Review 2012, www.housingeurope.eu/resource-105/thehousing-europe-review-2012.

Cedefop (2013), Early leaving from VET in Slovakia, Cedefop Report. 
Cohen W.M. and D.A. Levinthal (1989), "Innovation and learning: The two faces of R\&D”, The Economic Journal, Vol. 99.

Combes, P-P., G. Duranton and L. Gobillon (2008), "Spatial wage disparities: Sorting matters!", Journal of Urban Economics 63(2):723-42.

Criscuolo, Ch., , D. Czarnitzki, C. Hambro and J. Warda (2009), "Design and Evaluation of tax incentives for business Research and Development: Good practice and future Development", final report submitted to the Expert Group on Impacts of R\&D tax incentives to the European Commission, Directorate General - Research.

D'Costa, A. et al. (2013), "Structure, Policies, Institutions and Regional Growth", Regional Development Working Papers, OECD Publishing.

Dijskara L., P. Annoni and K. Kozovska (2011), "EU regional competitiveness index”, EU Working Papers n.0.2/2011.

Kocker and Rosted (2010), Promoting cluster excellence: Measuring and benchmarking the quality of cluster organisations and performance of clusters, VDI/VDE Innovation and Technik GmbH, FORA.

European Commision (2008), Cohesion Policy 2007-13: National Strategic Reference Frameworks, European Union Regional Policies, EC, Brussels

European Commission (2013), "PES Approaches for Sustainable Activation of Low Skilled Adults and Youths: Work-first or Train-first?”, Analytical Papers, DG Employment, Social Affairs and Inclusion, EC, Brussels.

European Commission (2014), "Assessment of the 2014 national reform programme and stability programme for Slovakia”, Commission Staff Working Documents (2014)426 final, EC, Brussels

European Commission, Employment, Social Affairs and Inclusion, Public Employment Services (http://ec.europa.eu/social/main.jsp?catId=105\&langId=en)

ECB (2003), "Structural Factors in the EU Housing Markets", European Central Bank.

EU (2012), Mind the gap: education inequality across the EU regions, EU Report authored by the NESSE network.

EU (2014), Innovation Union Scoreboard, European Union.

Eurostat (2010), Minimum wage statistics, epp.eurostat.ec.europa.eu/cache/ITY OFFPUB/KS-32-11798/EN/KS-32-11-798-EN.PDF.

Fidrmuc, J. (2004), "Migration and regional adjustment to asymmetric shocks in transition economies", Journal of Comparative Economics, vol. 32.2.

Griffith R., S. Redding and J. van Reenen (2004), "Mapping the Two Faces of R\&D: Productivity Growth in a Panel of OECD Industries", The Review of Economics and Statistics, MIT Press, Vol. 86(4).

Grubb, D. (1999), "Lessons from Education and training for youth: five precepts", in Preparing Youth for the 21st Century: the Transition from Education to the Labour Market, OECD Publishing. 
Handel, MJ. (2012), Trends in Job Skill Demands in OECD countries, OECD Social, Employment and Migration Working Papers n.143

Harvan, P. (2010), "Evaluation of Efficiency and Effectiveness of spending on active labour market policies”, Economic Analysis No. 20, Financial Policy Institute, Slovak Republic.

Haugh, D. (2013), "From brain to bricks", OECD Working Papers No. 1094, OECD Publishing.

Hüfner, F. (2009), “Adjusting Housing Policies in Slovakia in light of Euro Adoption”, Economics Department Working Papers 682, OECD Publishing.

INESS (2013), Minimálna mzda - účinný nástroj na zvyšovanie nezamestnanosti, www.iness.sk/media/file/pdf/publikacie/Minimalna\%20mzda_Final.pdf.

Ingstrup M.B. and Damgaard T. (2012), Cluster facilitation from a cluster life cycle perspective, European Planning Studies, Vol. 21.4

Keogh, H. (2009), The state and development of adult learning and education in Europe, North-America and Israel, Regional synthesis report, UNESCO Institute for Lifelong Learning, Hamburg.

Kluve, J. (2010), “The effectiveness of European active labour market programs”, Labour Economics 17.

Martin, J. and D. Grubb, (2001), "What work and for whom: a review of OECD countries 'experiences with active labour market policies", Institute for Labour Market Policy Evaluation Working Papers, No. 14, IFAU.

MDVRR (2007), Ministerstvo výstavby a regionálneho rozvoja Slovenskej republiky, Národný Strategický Referenčný Rámec 2007-2013.

MoF (2014), Ministerstvo dopravy, výstavby a regionálneho rozvoja SR, Ministerstvo financií SR (2014), Operačný program Integrovaná infraštruktúra 2014-2020.

MPSVR (2014), Operačný program Ludské zdroje na programové obdobie 2014-2020, Ministerstvo práce, sociálnych vecí a rodiny SR.

MPRV (2011), Hodnotenie výkonu činnosti sprostredkovatel'ských orgánov pod Riadiacim orgánom pre ROP, Hodnotiaca správa, Ministerstvo pôdohospodárstva a rozvoja vidieka SR.

MV (2014), Operačný program efektívna Verejná správa, Ministerstvo vnútra slovenskej republiky.

NDSAS, www.ndsas.sk/useky-janovce---jablonov--ii-usek/44223s43600c.

NRP (2014), National Reform Programme of the Slovak Republic, April (NRP), Slovak Government, Government Office.

Nickell, S.J. (1998), “Unemployment: Questions and some Answers”, Economic Journal, 108(448).

Oswald, A.J. (1996), "A Conjecture on the Explanation for High Unemployment in the Industrialized Nations", Part I, Warwick Economics Research Papers 475.

OECD (2001), Recent labour market development and prospects, in OECD Employment Outlook, OECD Publishing. 
ECO/WKP(2015)29

OECD (2004), Improving Skills for More and Better Jobs: Does training make a Difference? In OECD Employment Outlook, OECD Publishing.

OECD (2005a), How Persistent are Regional Disparities in Employment, in OECD Employment Outlook, OECD Publishing.

OECD (2005b), "Increasing Financial Incentives to Work: The Role of In-work Benefits", in OECD Employment Outlook, OECD Publishing.

OECD (2005c), Promoting Adult Learning, OECD Publishing.

OECD (2007), Jobs for Youth; Slovak Republic, OECD Publishing

OECD, (2008), OECD Territorial Reviews: Poland, OECD Publishing.

OECD (2009a), The employment and social policy response to the job crisis, in OECD Employment Outlook, OECD Publishing.

OECD (2009b), Economic Surveys: Slovakia, OECD Publishing.

OECD (2009c), Clusters innovation and entrepreneurship, OECD publishing.

OECD (2010a), Economic Survey of Germany, OECD Publishing.

OECD (2010b), Innovation Vouchers, in OECD Innovation Handbook, OECD Publishing.

OECD (2011a), Housing and the Economy: Policies for renovation in Going for Growth 2011, OECD Publishing.

OECD (2011b), "Does Participation in Pre-primary Education Translate into Better Learning Outcomes at School?", in PISA in Focus 1, OECD Publishing.

OECD (2011c), Regions and Innovations, OECD Publishing.

OECD (2011d), Economic Policy Reforms: Going for Growth 2011, OECD Publishing

OECD (2012a), Promoting growth in all regions, OECD Publishing.

OECD (2012b), Economic Surveys: Slovakia, OECD Publishing.

OECD (2012c), Economic Surveys: Portugal, OECD Publishing.

OECD (2012e), Quality matter in early childhood education and care, OECD Publishing.

OECD (2013a), OECD Regions at a Glance, OECD Publishing.

OECD (2013b), Education at a Glance, OECD Publishing.

OECD (2013c), Activating Jobseekers: Lessons from Seven OECD countries, in OECD Employment Outlook, OECD Publishing. 
OECD (2013d), Excellence through Equity: Giving Every Student the Chance to Succeed, Vol. II, OECD Publishing.

OECD (2013e), Economic Surveys: Brazil, OECD Publishing.

OECD (2013f), “Spending on Transport Infrastructure 1995-2011”, International Transport Forum, OECD Publishing.

OECD (2013g), Science and Technology and Innovation Scoreboard, OECD Publishing.

OECD (2013h) Trade in value added: Country Note Slovakia, OECD Publishing.

OECD (2013i), Supporting Investment in Knowledge Capital, Growth and Innovation, OECD Publishing.

OECD (2013j), Investing together - Working effectively across levels of government, OECD Publishing.

OECD (2014a), Recommendation of the OECD Council on Effective Public Investment Across Levels of Government, OECD Publishing.

OECD (2014b), Public Governance Reviews Slovak Republic Developing a Sustainable Strategic Framework for Public Administration Reform, OECD Publishing.

OECD (2014c), Economic Survey: Turkey, OECD Publishing.

OECD (2014d), OECD Economic Surveys: Slovakia, OECD Publishing.

Ok, W. and P. Tergeist (2003), "Improving Workers' Skills: Analytical Evidence and the Role of the Social Partners”, Social, Employment and Migration Working Papers No. 10, OECD Publishing.

van Ommeren, I.N. and M. van Leuvensteijn (2005), "New Evidence of the Effect of Transaction Costs on Residential Mobility", Journal of Regional Science 45.

Orszag, J.M. and D.J. Snower (2003), “Designing employment subsidies”, Labour Economics 10(5).

PAS (2013), Konkurencieshopne regiony 21, Podnikatelska aliancia Slovenska.

van Pottelsberghe de la Potterie and F. Lichtenberg (2001), "Does Foreign Direct Investment Transfer Technology Across Borders?”, Review of Economics and Statistics, 83(3), 2001, 490-497.

PUSR (2011), Problémy v sektore železničnej dopravy zo sút’ažného hl’adiska, Protimonopolný Úrad Slovenskej Republiky.

RIS3 (2013), Innovation Strategy for Smart Specialisation in Slovak Republic Report, Ministry of Economy.

Rosenthal, S.S. and W. Strange (2004), "Evidence on the Nature and Sources of Agglomeration Economies", in Handbook of regional and urban economics, Vol. 4, Henderson, V. and J.- F. Thisse (eds.), 2119-71, Amsterdam, North- Holland.

Roth, P. (2012), “Dálnice D1, úsek Turany - Hubová, Hodnocení vlivů na lokality soustavy Natura 2000”. 
Sutherland, D., S. Araujo, B. Egert and T. Kozluk (2009), "Infrastructure Investment: Links to Growth and the Role of Public Policies", Economics Department Working Papers 546, OECD Publishing.

UNDP (2012), Report on the living conditions of Roma households in Slovakia 2010, UNDP Regional Bureau for Europe and the Commonwealth of Independent States, Bratislava.

UVO www.uvo.gov.sk/evestnik/-/vestnik/228188.

Vagac, L. (2013), Internal Labour mobility in Slovakia, European Employment Observatory, June.

Westergaard-Nielsen, N. and A.R. Rasmussen (1999), "The Impact of subsidies on the number of Aprenticeships", Research in labor economics 18.

Westmore, B. (2013), "R\&D, Patenting and Productivity: The Role of Public Policy”, Economics Department Working Papers n.1047, OECD Publishing.

World Bank (2012), Policy Advice on the Integration of Roma in the Slovak Republic, World Bank, Washington, 
ECO/WKP(2015)29

\section{WORKING PAPERS}

The full series of Economics Department Working Papers can be consulted at www.oecd.org/eco/workingpapers

1210. Skill mismatch and public policy in OECD countries

(April 2015) by Müge Adalet McGowan and Dan Andrews

1209. Labour market mismatch and labour productivity: evidence from PIAAC data

(April 2015) by Müge Adalet McGowan and Dan Andrews

1208. Maintaining an efficient and equitable housing market in Belgium

(April 2015) by Sanne Zwart

1207. Determinants of the low female labour force participation in India

(April 2015) by Piritta Sorsa, Jan Mares, Mathilde Didier, Caio Guimaraes, Marie Rabate,

Gen Tang and Annamaria Tuske

1206. Strengthening skill use and school-to-work transitions in the Czech Republic

(April 2015) by Sónia Araújo and Petr Malecek

1205. Reforming the tax on immovable property: taking care of the unloved:

(April 2015) by Hansjörg Blöchliger

1204. Taxation and investment in Colombia

(April 2015) by Sarah Perret and Bert Brys

1203. Efficiency and contestability in the Colombian banking system

(April 2015) by Christian Daude and Julien Pascal

1202. Fiscal decentralisation in Colombia: new evidence regarding sustainability, risk sharing and "fiscal fatigue"

(April 2015) by Guillaume Bousquet, Christian Daude and Christine de la Maisonneuve

1201. Effects of economic policies on microeconomic stability

(April 2015) by Boris Cournède, Paula Garda and Volker Ziemann

1200. The 2013 update of the OECD's database on product market regulation - policy insights for $O E C D$ and non-OECD countries

(April 2015) by Isabell Koske, Isabelle Wanner, Rosamaria Bitetti and Omar Barbiero

1199. Improving taxes and transfers in Australia

(April 2015) by Philip Hemmings and Annamaria Tuske

1198. Federal-state relations in Australia

(April 2015) by Vassiliki Koutsogeorgopoulou and Annamaria Tuske

1197. Sharing the fruits of growth with all Mexicans

(April 2015) by Eduardo Olaberriá and Valéry Dugain

1196. What makes Mexicans happy?

(April 2015) by Valéry Dugain and Eduardo Olaberriá 
1195. Improving the labour market integration of immigrants in Belgium (March 2015) by Álvaro Pina, Vincent Corluy and Gerlinde Verbist

1194. Raising the potential of the domestically oriented sector in Germany (March 2015) by André Eid and Andrés Hutfilter

1193. Improving transport infrastructure in Russia (March 2015) by Alexander Kolik, Artur Radziwill and Natalia Turdyeva

1192. Improving the business climate in Russia

(March 2015) by Arthur Radziwill and Yana Vaziakova

1191. Determinants of female entrepreneurship in India

(March 2015) by Arnaud Daymard

1190. The changing role of the exchange rate for macroeconomic adjustment (March 2015) by Patrice Ollivaud, Elena Rusticelli and Cyrille Schwellnus

1189. Boosting productivity in Russia: skills, education and innovation (March 2015) by Lilas Demmou and Andreas Wörgötter

1188. Boosting growth and reducing informality in Mexico (March 2015) by Sean Dougherty

1187. The conduct of monetary policy in the future: instrument use

(March 2015) by Kei-Ichiro Inaba, Rory O'Farrell, Łukasz Rawdanowicz and Ane Kathrine Christensen

1186. A constant market share analysis of Spanish goods (February 2015) by Alberto Gonzalez Pandiella

1185. Raising the economic participation of women in India - a new growth engine? (February 2015) by Piritta Sorsa

1184. Improving health outcomes and health care in India (January 2015) by Isabelle Joumard and Ankit Kumar

1183. Challenges and opportunities of India's manufacturing sector (January 2015) by Isabelle Joumard, Urban Sila and Hermes Morgavi

1182. The heterogeneity of product market regulations (December 2014) by Jean-Marc Fournier

1181. Implicit regulatory barriers in the EU single market: new empirical evidence from gravity models

(December 2014) by Jean-Marc Fournier, Aurore Domps, Yaëlle Gorin, Xavier Guillet and Délia Morchoisne

1180. Can pro-growth policies lift all boats? An analysis based on household disposable income (December 2014) by Orsetta Causa, Alain de Serres and Nicolas Ruiz 